\title{
A diverse ichnofauna from the Cambrian Stage 4 Wulongqing Formation near Kunming (Yunnan Province, South China)
}

\author{
Bernd Weber, ShiXue HU, Michael Steiner \& FANGCHEN ZHAO
}

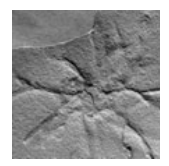

\begin{abstract}
A diverse and well-preserved ichnofauna from the Cambrian (Stage 4: Canglangpuan) Wulongqing Formation (Kunming area, Yunnan Province) is reported here for the first time in detail. Early Cambrian ichnoassemblages are common and have been described from many localities worldwide; however, they are rarely associated with a significant body fossil record that enables both a well-defined biostratigraphic calibration of the related ichnofauna and a direct comparison with the possibly related trace originators, as is the case with the Wulongqing Formation. The ichnofauna consists of various simple bedding-plane-parallel and sub-horizontal traces of Planolites-type as well as of branching, treptichnid-type burrows, Phycodes- and Teichichnus-type "spreiten", star-shaped trace structures associated with short, central and vertical burrow structures, and arthropod traces of the Diplichnites-type. Large, star-shaped trace fossils belonging to a new ichnotaxon (Guanshanichnus glockerichnoides igen. et isp. nov.) are reported from the Yangtze Platform for the first time and represent the hitherto oldest (equivalent to Botoman regional stage of Siberia) known evidence of this trace type and further global-scale evidence of this trace type from a shallow-water environment. Arthropod traces appear in less abundance in the middle part of the formation. Several arthropod traces display a significant, V-shaped, paired arrangement of scratch marks onthe bedding plane; their morphology and size correspond with co-occurring trilobite taxa from the Wulongqing Formation, probably indicating the preservation of trilobite resting traces. The Shitangshan trace fauna as part of the Guanshan Fauna provides new insights into the palaeoecology and taphonomy of Chengjiang-type fossil Lagerstätten. - Key words: ichnofossils, Wulongqing Formation, Cambrian Stage 4, Guanshan, Yunnan Province.
\end{abstract}

WEBER, B., HU, S.X., STEINER, M. \& ZHAO, F.C. 2012. A diverse ichnofauna from the Cambrian Stage 4 Wulongqing Formation near Kunming (Yunnan Province, South China). Bulletin of Geosciences 87(1), 71-92 (10 figures). Czech Geological Survey, Prague. ISSN 1214-1119. Manuscript received October 1, 2010; accepted in revised form October 4, 2011; published online February 22, 2012; issued February 29, 2012.

Bernd Weber \& Michael Steiner, Institut für Geologische Wissenschaften \& Institut für Paläontologie, Freie Universität Berlin, Malteser Str. 74-100, D-12249 Berlin, Germany; bweber@zedat.fu-berlin.de• Shixue Hu, Yunnan Institute of Geological Sciences, No. 87, Dongfeng Lane, East Dongfeng Road, 650051 Kunming, Yunnan Province, China • Fangchen Zhao, State Key Laboratory of Palaeobiology and Stratigraphy, Nanjing Institute of Geology and Palaeontology, Chinese Academy of Sciences, 210008 Nanjing, China

The south-western part of the Yangtze Platform yields the famous Chengjiang fossil Lagerstätte which, in addition to diverse skeletal fossils, provides an extraordinary record of soft-body-preserved (Burgess Shale-type) invertebrate fauna (for an overview see e.g. Hou et al. 2004, Gabbot et al. 2004, Luo et al. 1999). The Chengjiang Biota is one of the oldest Burgess Shale-type biotas known to date and therefore is crucial in the discussion on the early Cambrian metazoan radiation event ("Cambrian Explosion"). Nevertheless, because of their specific origin the Chengjiang- and Burgess Shale-type fossil Lagerstätten contain no - or very rarely a poorly preserved trace fossil record.
The Guanshan Biota of the Wulongquing Formation (Cambrian Stage 4: upper Canglangpuan regional stage; probably equivalent to the Botoman Stage of Siberia) represents a somewhat younger evolutionary stage and differs in the ecological setting from the older Chengjiang-type Lagerstätten on the Yangtze Platform (Qiongzhusian: Yuanshan Member) by its shallower depositional environment incorporating more abundant siltstone and sandstone interbeds within the mudstone sequences. Such interstratified silt beds provide ideal conditions for the preservation of trace fossils. In contrast to the Chengjiang Lagerstätte, trace fossils are very abundant in the Wulongqing Formation. Nevertheless, they have never been systematically investigated so far. 


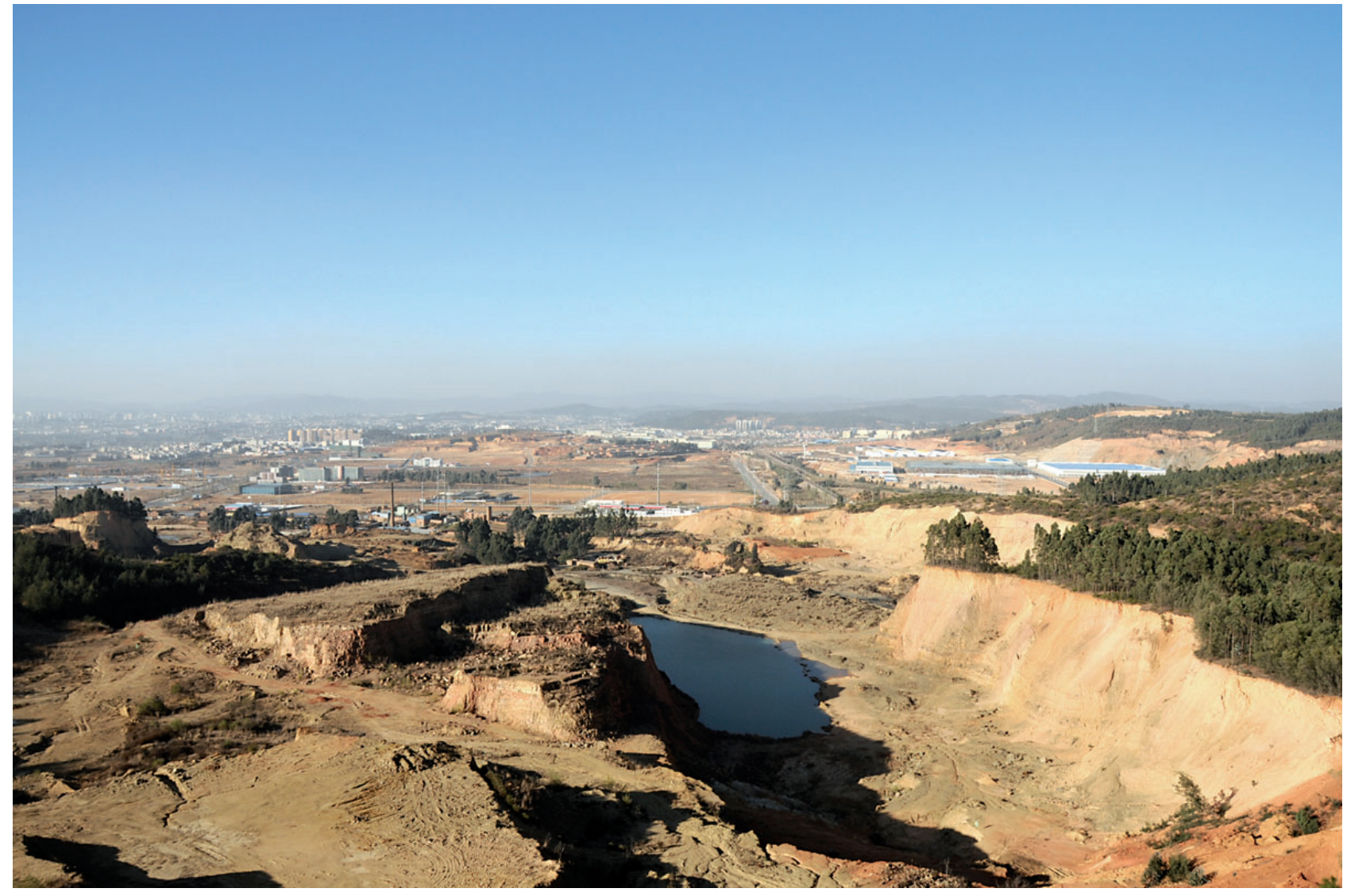

Figure 1. The Shitangshan quarry near the village Guangwei, north of Kunming (Yunnan Province) in autumn 2009.

\section{Age and geological setting of the Wulongqing Formation}

The Wulongqing Formation is well exposed at Gaoloufang village and in the Shitangshan quarry in the Guanshan area (Fig. 1), close to the village of Guangwei, near Kunming. Outcrops of the Wulongqing Formation are widespread in the Yunnan Province (Kunming-Wuding, Huize, and Malong-Yiliang areas). The localities at Gangtoucun and Gaoloufang near Kunming City are important outcrops, as well as the Sapushan and the Wushishan localities in $\mathrm{Wu}-$ ding County (Fig. 2).

In the Shitangshan quarry, the Wulongqing Formation is about $60 \mathrm{~m}$ thick and overlies the fine-grained sandstones of the Hongjingshao Formation (Fig. 2). The contact to the underlying unfossiliferous Hongjingshao Formation is characterized by a several-decimetre-thick basal conglomerate of the lowermost part of the Wulongqing Formation, probably indicating a regional transgression event in SW China (Fig. 3A). The top of the Wulongqing Formation is not preserved in the Shitangshan Quarry. The Wulongqing Formation consists of a monotonous sequence of mudstones with siltstone intercalations (Fig. 2), the lower part of which is mainly composed of mudstone with few thin-bedded silt-sandstone layers. The micaceous siltstone and fine-grained sandstone beds become more abundant towards the top of the Wulongqing Formation. The mudstone beds display erosive bases and an upward fining. Multiple-graded silt-mud couplets are frequent within the mudstone beds. Sole marks, trace fossils and microbial mat structures (Fig. 3C) are common at the base of the siltstone beds. There are several similarities to lower and middle Cambrian sequences in Baltica: as mentioned in Hu et al. (2010; Weber, pers. observation), the sedimentary regime and lithology (as well as several components of the Wulongqing ichnoassemblage) resemble the (middle) Cambrian Äleklinta section of Öland in SE Sweden (e.g., Martinsson 1965, Porada et al. 2008).

The age of the Wulongqing Formation is biostratigraphically well constrained by trilobite zonation. The Wulonqing Formation is characterized by the Palaeolenus Zone at the base and the Megapalaeolenus Zone (= upper Canglangpuan, Stage 4 of the South Chinese regional biostratigraphical zonation) at the top (Fig. 2). According to the South Chinese regional scale (e.g. Hu et al. 2010), the sequence represents a stratigraphic equivalent to the Balang Formation (Guizhou Province) and the Shipai Formation of the Three Gorges area of Hubei Province, which both contain a similar macrofauna (Luo et al. 1994, Pen et al. 2005, Zhang \& Hua 2005). According to the global Cambrian (ISC) zonation (the Guanshan Fauna belongs to 

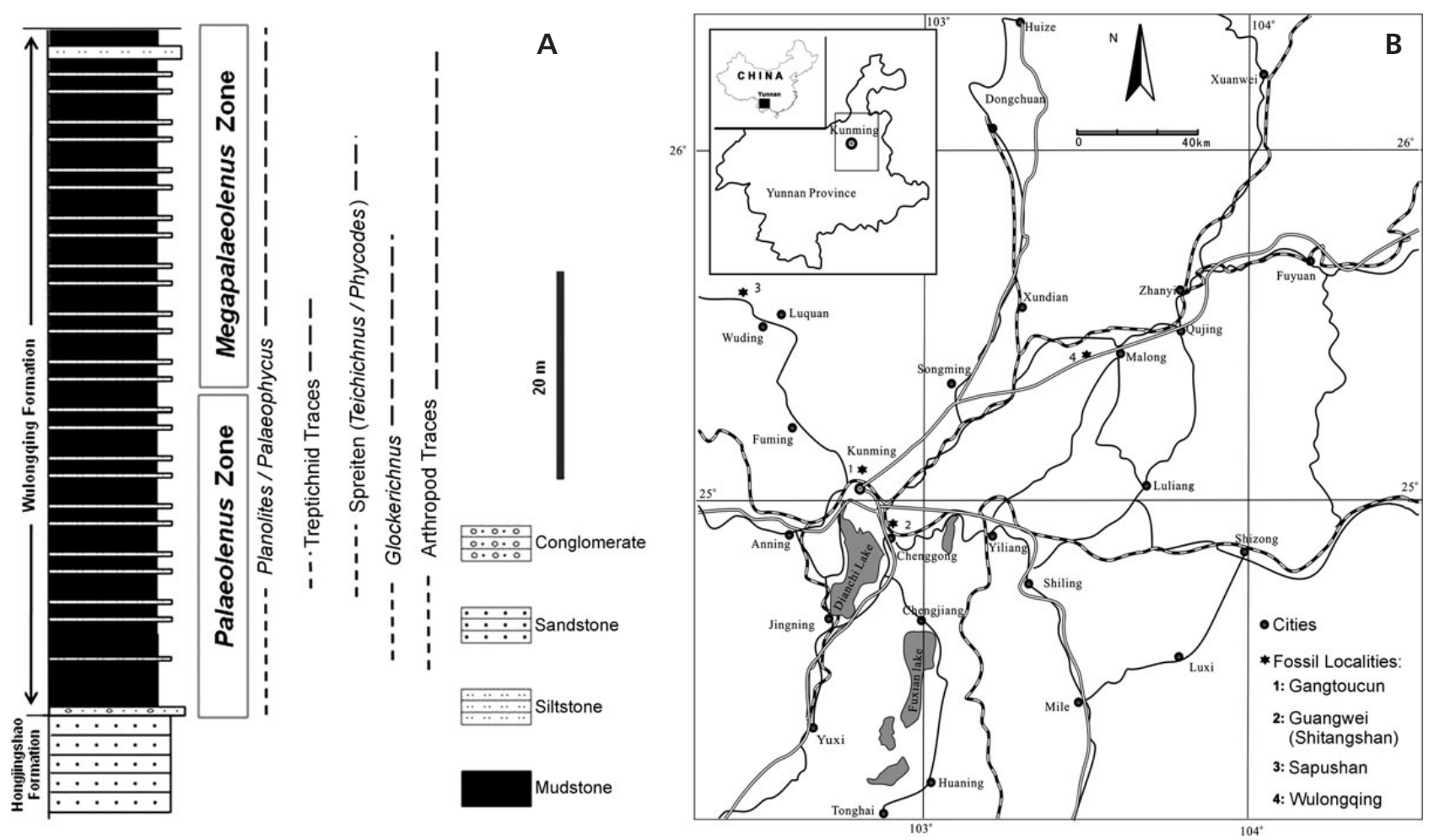

Figure 2. A - the Shitangshan section (Wulongqing Formation) showing approximate stratigraphic distribution of characteristic groups of trilobites (trilobite zones) and trace fossils. $\bullet$ B - a sketch map of the Kunming area showing the most important outcrops of the Wulongqing Formation (Shitangshan quarry is the number 2 near the village Guangwei).

Stage 4, Series II ( ca 515-510 My). The Wulongqing Fauna can be correlated with the Botoman Stage of Siberia (Sinsk fossil Lagerstätte: Ivantsov et al. 2005, Ponomarenko 2005) and the Emu Bay fossil Lagerstätte in Australia (e.g., Paterson \& Brock 2007). A more detailed description of the geological setting, biostratigraphic correlation, taphonomy and macrofossil content of the Wulongqing Formation was published by $\mathrm{Hu}$ et al. (2010).

\section{Ichnofauna}

Luo et al. (2008) and Hu et al. (2010) briefly reported on the ichnofauna from the Wulongqing Formation. A tentative ichnotaxonomy was given in a checklist of ichnotaxa in $\mathrm{Hu}$ et al. (2010; partly based on preliminary information from field studies by B.W., personal communication); however, after a careful and more detailed study of the ichnofauna for the present paper, the ichnotaxonomy of the trace assemblage had to be partly revised and in some cases also changed. The Guanshan ichnoassemblage consists of seven groups of trace fossils:

(i) Simple, horizontally and sub-horizontally inclined or dipping, flat-U-shaped burrows of the Planolites-Palaeophycus-type; beds with partly intense bioturbation,

(ii) Gordia- and Olenichnus-type traces, (iii) Branched Treptichnus- and Thalassionides-type traces as well as complex Phycodes- and Teichichnus-type spreiten,

(iv) Short vertical traces,

(v) Short, vertical, funnel-shaped burrows, partly associated with star-shaped horizontal structures of Glockerichnus-like shape,

(vi) Arthropod traces,

(vii) Faecal pellets (coprolites).

\section{(i) Simple, bedding-parallel to shallow-dipping burrows}

Mud- and siltstone horizons with intense bioturbation are very common throughout the Wulongqing Formation (Fig. 3B). Along with several non-specific horizontal to sub-horizontal burrows, the trace spectrum contains typical Planolites- and Palaeophycus-type traces:

\section{Planolites Nicholson, 1873}

Figure 3B, D

Description and discussion. - Short, straight or curved, horizontally to somewhat obliquely dipping burrows are 
common in the Wulongqing Formation and are attributed to the ichnogenus Planolites (Fig. 3D), partly forming sediment beds with intense bioturbation.

Planolites-type traces are mostly unbranched and can vary in shape and width between 3 and $10 \mathrm{~mm}$. The burrows mostly possess smooth walls or may rarely show irregular ornamentation. The burrows are filled with sediment that (in contrast to the related ichnogenus Palaeophycus, see below) clearly differs from the surrounding rock matrix. This phenomenon can be explained by the activity of a sediment (deposit) feeder (e.g., Pemberton \& Frey 1982, Fillion \& Pickerill 1990, Kappel 2002). The characteristic structure of the Planolites-type traces was produced by active back-filling of faecal particles or pellets after passing the alimentary canal ("Stopftunnel") and was caused by an unknown infaunal trace maker. Various ichnospecies have been described on the basis of typical ranges of burrow diameters and surface sculptures (bulges, granulations), e.g., Planolites beverleyensis Billings, 1862 (type ichnospecies), maximum burrow diameter about 5-10 mm, and the mostly smaller and shorter Planolites montanus Richter, 1937, maximum burrow diameter about 3-7 mm. Planolites-type traces are very common during the entire Phanerozoic era and appear already in late Precambrian shallow-water deposits (Häntzschel 1975). Related structures are also known from recent abyssal sediments (e.g., Ekdale et al. 1984).

The majority of the Planolites-type traces in the Shitangshan ichno-assemblage belong to Planolites aff. beverleyensis. Planolites- and Palaeophycus-type traces (compare below) mostly occur in large numbers in certain beds. At least some of them are therefore to be interpreted (after Bromley 1996) as combined domichnia and/or pascichnia of opportunistic deposit feeders consuming nutrient-rich event beds in storm deposits. Planolites (and probably also Palaeophycus) are therefore involved in the formation of intensively bioturbated horizons of the Shitangshan section as demonstrated in Fig. 3B and D.

\section{Palaeophycus Hall, 1847}

Figure 3E

Description and discussion. - Straight or slightly curving bedding-parallel, rarely inclined traces with a smooth (or irregular, longitudinally sculptured) surface, mostly larger than the Planolites-type traces, are also common in the Wulongqing Formation and are here attributed to the ichnogenus Palaeophycus.

According to Pemberton \& Frey (1982), the ichnogenus Palaeophycus can be distinguished from Planolites by lined trace walls as well as by an open and secondarily filled domichnial architecture. In contrast to Planolites, the sediment fillings of Palaeophycus-type traces usually do not differ from the surrounding sediment matrix.

Palaeophycus is mostly unbranched or rarely branched. As with Planolites, however, pseudo-branching is often caused by the crossing of different burrow generations. In contrast to the typical network-shaped branching structures of Thalassinoides ( $c f$. below), true branching structures in Palaeophycus-type traces are always irregular and never show bulges in the branching areas.

Kappel (2002, see also Pemberton \& Frey 1982) has emphasized that, along with these ichnotaxonomic dissimilarities, Planolites and Palaeophycus also display palaeoethological differences as Planolites represents the feeding burrow of an infaunal and mobile suspension feeder, whereas Palaeophycus is an open and passively filled domichnion of an (epifaunal) suspension feeder or a predator.

As in the case of Planolites-type traces, the ichnotaxonomic differentiation of ichnospecies (distinguished by varying size range and surface ornamentation) of Palaeophycus is generally problematic and depends on the trace taphonomy. The specimen of "Planolites montanus" Richter, 1937 from the time-equivalent Wushishan Formation (Wuding County) figured by Luo et al. (2008, p. 105; pl. 39, fig. 3) displays clearly visible, lined burrow walls and is therefore better assigned to Palaeophycus tubularis Hall, 1847. The traces figured here (Fig. 5E) show no true surface ornamentations and are provisionally described as Palaeophycus isp.

\section{Plagiogmus Roedel, 1929}

Figure 3G

Description and discussion. - The ichnogenus Plagiogmus was first reported by Roedel (1929) from glacial erratic boulders of early Cambrian sandstone from southern

Figure 3. A - the conglomerate bed at the base of the Wulongqing Formation ( $c f$. Fig. 2A), hammer head: $20 \mathrm{~cm}$. $\bullet$ B - intense bioturbation in a silt-sandstone bed in the lower-middle part of the Shitangshan section, scale: $5 \mathrm{~cm}$. $\bullet \mathrm{C}$ - mud-siltstone surface with wrinkle marks commonly indicating microbial mat structures. $\bullet$ D - numerous Planolites-type burrows. The light color of the burrows differs from the darker matrix indicating a different filling of the burrows. $\cdot$ E - hyporeliefs of large Palaeophycus-type traces. The colour and composition of the burrow fillings is identical with the surrounding sedimentary matrix indicating an open primary burrow secondarily collapsed and filled with the surrounding sediment. $\bullet \mathrm{F}-\mathrm{a}$ problematic specimen of ?Psammichnites showing the fine transversal annulation. A median ridge (or furrow) is only faintly preserved in the left part of the trace. $\bullet \mathrm{G}-\mathrm{a}$ problematic and unique specimen of ?Plagiogmus. The left part of the trace displays the typical wide-spaced and relative broad ridges of Plagiogmus-type traces (arrows). $\bullet \mathrm{H}$ - siltstone slab with numeros Olenichnus-type traces. Multiple branching and crossing traces form an irregular net-shaped appearance of this trace fossil. Scales in C-H: $1 \mathrm{~cm}$; coins: $2 \mathrm{~cm}$. 
Bernd Weber et al. • Ichnofauna from the Cambrian Stage 4, South China
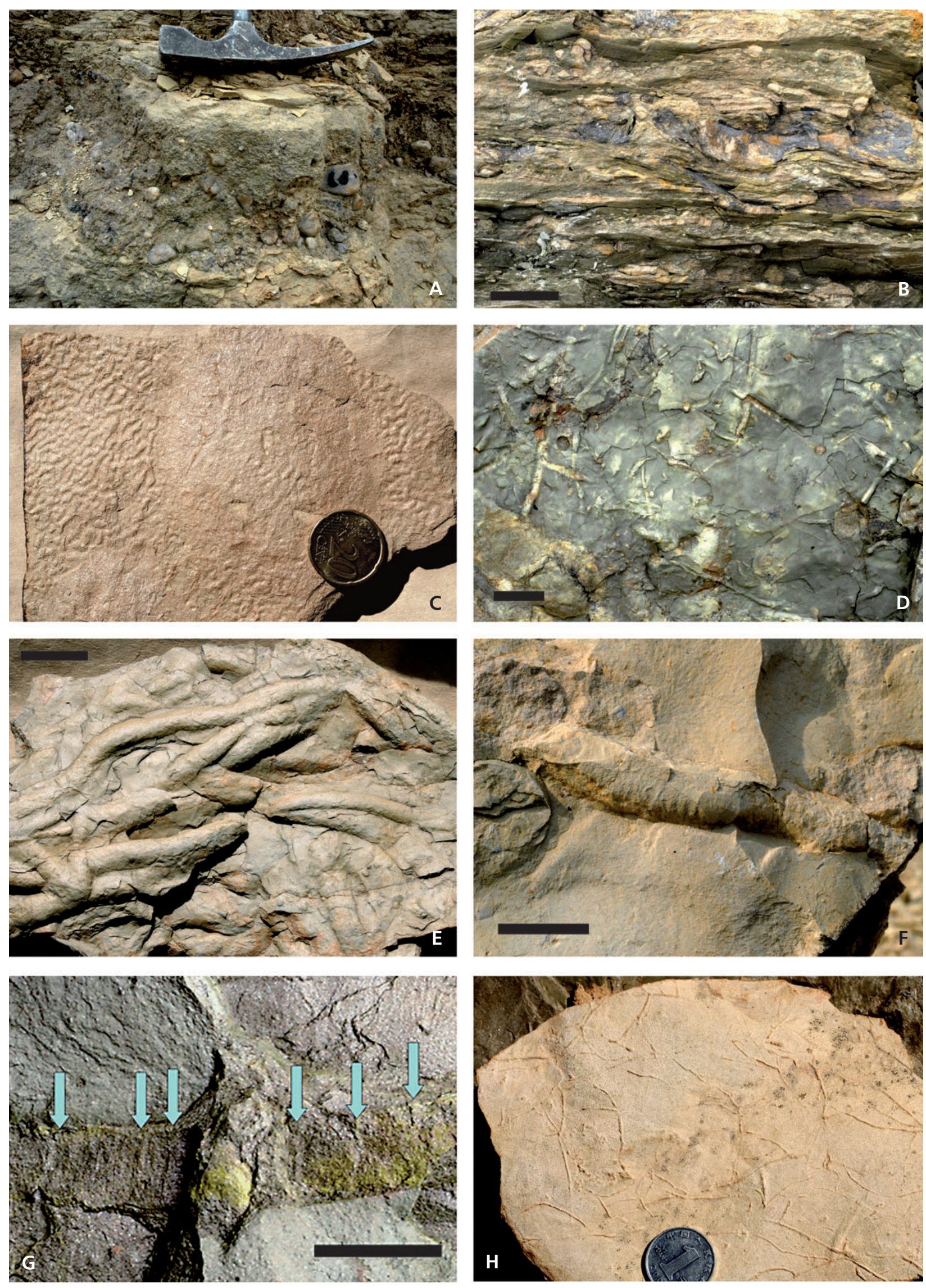
Scandinavia (e.g., Hucke 1967, Häntzschel 1975, Jaeger \& Martinsson 1980). The trace was reported from the basal Cambrian of Finnmark (Norway) by Banks (1970), from the early Cambrian of East Greenland (Cowie \& Spencer 1970) and from the early Cambrian of central Australia (McIlroy \& Heys 1997). Plagiogmus arcuatus is characterized by flat, smooth, ribbon-shaped traces (about 1-2 cm wide). They are parallel to the bedding plane, straight or slightly curved and display pronounced transverse ridges (cf. Häntzschel 1975). Zhu (1997) discussed a possible synonymy of Plagiogmus and Psammichnites; however, comparison with the type material in Roedel's description (1929) shows that Plagiogmus clearly differs from Psammichnites by its prominent and wide-spaced transversal ridges.

This ichnomorphology is visible especially in the left part of the trace in Fig. 3G ( $c f$. arrows in Fig. 3G). The figured specimen, however, represents a hitherto unique (but not well-preserved) report of this ichnogenus in the Wulongqing Formation. Further material is required to confirm that this represents the first evidence of the ichnogenus Plagiogmus in the early Cambrian of China.

\section{Psammichnites Torell, 1870}

Figure 3F

Description and discussion. - The ichnogenus Psammichnites Torell, 1870 is characterized by large (2-3 cm wide) ribbon-shaped trails with narrow longitudinal ridges or furrows and fine transverse and closely spaced ridges ( $c f$. Häntzschel 1975, W98). The trace type is locally abundant but not a particularly common trace fossil in the basal Cambrian of Baltica, especially in sections of the Hardeberga sandstone in southern Sweden (e.g. Torell 1868, Hadding 1929). Psammichnites (especially Psammichnites gigas Torell) is also known from Pleistocene erratic boulders in Denmark and northern Germany (e.g. Rohde 2009, figs 1-7). The large and prominent traces were interpreted as repichnia of large (non-shelly) Palaeozoic molluscs ( $c f$. Häntzschel 1975).

The ichnogenus Psammichnites has been repeatedly mentioned from basal Cambrian deposits in China: Luo et al. (2008) figured new fossil material from the early Cam- brian Malong Fauna (Jinning area, Yunnan). On the basis of a well-preserved specimens (Luo et al. 2008, pl. 40, figs 1,2), these authors established and described a new ichnospecies of Psammichnites (Psammichnites anningensis Luo \& Zhang, 2008 in Luo et al. 2008). Zhu (1997) reported well-preserved specimens of Psammichnites from the Shiyantou Formation of Meishucun (Yunnan). Finally, Hu et al. (2010) only mentioned Qipanshanichnus gyrus Luo et al., 1994 from the Guanshan Biota which is probably related to Psammichnites and probably to several other Pc-C Taphrhelminthopsis-like trace types (for discussion see Jensen 2003).

The specimen described herein (Fig. 3F) displays a faint transverse (narrow-spaced) annulation. A longitudinal ridge (or furrow), however, is also faintly preserved and absent in several parts of the trace. For that reason, we attribute this single specimen in Fig. 3F from the Shitangshan section only tentatively to the ichnogenus Psammichnites.

\section{?Olenichnid traces}

Figure $3 \mathrm{H}$

Description and discussion. - The fine straight or partly curved, bedding-parallel traces in Fig. $3 \mathrm{H}$ represent a single specimen and are here provisionally attributed to Olenichnus Fedonkin, 1985. The traces are mainly horizontal, with minor vertical inclination, and a few specimens display a faint, irregular, transversal annulation. They are multiple-branched and cross each other, forming an irregular, net-shaped structure. Numerous small knobs on the figured slab represent cross- cut vertical components of the burrow system. Olenichnus was also reported and described from the early Cambrian Mickwitzia sandstone, south-central Sweden, by Jensen (1997).

\section{Gordia Emmons, 1844}

Figure 4A

Description and discussion. - According to Häntzschel (1975), the ichnogenus Gordia is characterized by long and slender worm-like traces. They are of uniform thickness,

Figure 4. A - Gordia cf. marina Emmons on a mudstone-siltstone slab. The specimen displays the typical looping horizontal burrows of the ichnotaxon Gordia. $\bullet$ B - large (uncollectable) slab with hyporeliefs of Thalassinoides-type traces from the middle part of the Shitangshan section showing the typical T- or Y-shaped branching and the resulting net-shaped trace architecture of Thalassinoides. $\bullet \mathrm{C}$ - typical "broom-shaped" spreite of Phycodes-type from the middle part of the Shitangshan section. $\bullet$ D-F - two different ichnotaphonomic preservations of Treptichnus pedum from the lower-middle part of the Shitangshan section. $\bullet$ F - Teichichnus isp., a part of an exichnium of a Teichichnus spreite showing the stacked gutters forming a flat U-shaped spreite. - $\mathrm{G}$ - the characteristic image of a lateral cross-cutted Teichichnus spreite. $\bullet \mathrm{H}$ - exichnial preservation of a knob-shaped structure representing a circular central area of a Guanshanichnus specimen. On the right edge of the circular structure, some of the ray-shaped ridges are preserved. The specimen demonstrates that at least a part of the knob-shaped structures are (exichnial) preservations of the short vertical burrow structures of Guanshanichnus (cf. Fig. 5B-F). 
Bernd Weber et al. • Ichnofauna from the Cambrian Stage 4, South China
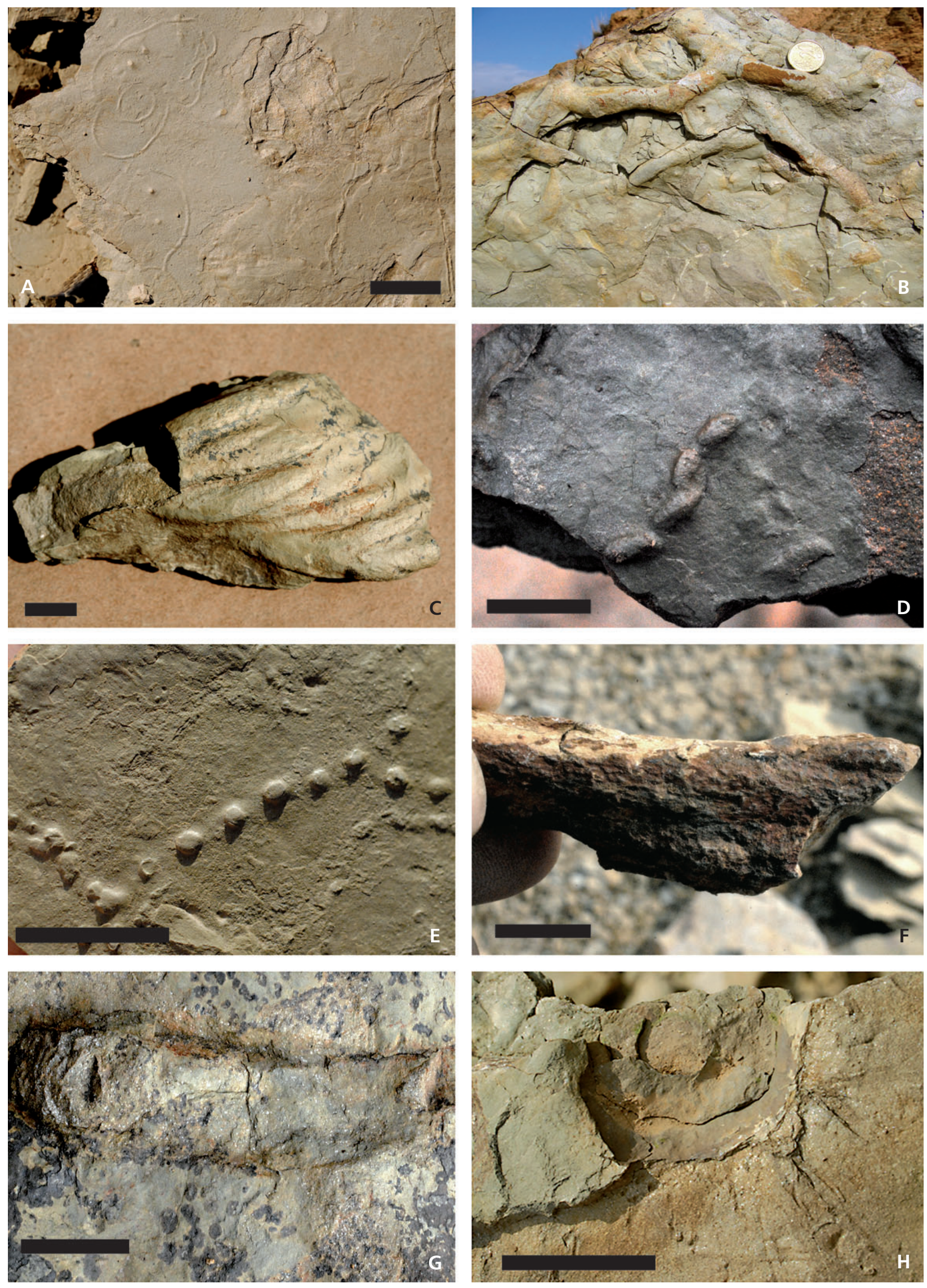
mostly irregularly winding and curved, sometimes looping and crossing, but never meandering. Häntzschel (1975) synonymized Gordia with the also common ichnogenus Helminthoidichnites Fitch, 1850. Hofmann \& Patel (1989), however, maintained these as separate ichnotaxa as Gordia typically displays self-crossings of the same burrow, whereas Helminthoidichnites never shows crossings (for a more detailed discussion see Jensen 1997). Gordia-type traces are very common worldwide and known from Ediacaran (e.g. Hofmann 1981) up to Cenozoic times. Yue et al. (2009) investigated Gordia marina in the (early middle) Cambrian Kaili Biota (Guizhou, South China) and their probably trophic interaction with Pararotadiscus carcasses. The trace originators are thought to be priapulids that fed on Pararotadiscus and several arthropod carcasses. The single slab in Fig. 4A collected from the Shitangshan quarry shows a looping trace on the left side, which displays a crossing of the same burrow in its upper part. Following Hofmannn \& Patel (1989), we attribute the trace to the ichnogenus Gordia (very likely Gordia marina Emmons, 1844; see also Peel 2010).

\section{(ii) Branched burrows and "spreiten"}

In contrast to the ubiquitous Planolites- and Palaeophycus-type traces, branched burrows and "spreiten" are generally more rare and seem to be restricted to the middle part of the Shitangshan section (see Fig. 2A).

\section{?Thalassinoides Ehrenberg, 1944}

Figure 4B

Description and discussion. - The ichnogenus was established by Ehrenberg (1944) and later emended by Kennedy (1967). Thalassinoides is characterized by three-dimensional and open burrow systems. Burrows are branching into Y- or T-shaped bifurcations forming horizontal (bedding plane parallel) networks that are connected to surface by vertical shafts (which were never observed in the Shitangshan specimens described here). The burrows are typically $10-15 \mathrm{~mm}$ wide and display swellings (usually up to $30 \mathrm{~mm}$ ) at the branching points ( $c f$. Häntzschel 1975). Thalassinoides is mainly known from Late Palaeozoic to Cenozoic occurrences. Myrow (1995) described a smaller type from the (middle) Cambrian to Lower Ordovician Peerless and Manitou formations in central Colorado as Thalassinoides horizontalis.

In the middle part of the Shitangshan section, beds with relatively thick bedding-parallel, T- and Y-shaped branching burrows are common. Similar traces were reported from an equivalent section near Wushishan (Wuding County), northwest of Kunming area (see Fig. 2) by Luo et al. (2008, p. 106, pl. 40/5) as Thalassinoides xiaoluoguiensis Luo, 1994. Zhu (1997) reported Thalassinoides-like traces from the Upper Yuanshan Formation (Haikou, Yunnan) which, however, only faintly display the Y-shaped network structure, with no swellings and no vertical shafts. Dornbos (2004) interpreted similar structures from the Meishucun section as Thalassinoides.

Thalassinoides xiaoluoguiensis Luo et al., 2008 is represented only by a unique specimen of a Y-shaped branching horizontal burrow. The specimens from the Wulongqing Formation figured here (Fig. 4B) represent a more typical Thalassinoides-type trace as they display the typical network of multiple Y- and T-shaped branching burrows with swellings at the branching points. Both remain questionable because of the lack of vertical shaft structures.

\section{Phycodes Richter, 1850}

Figure 4C

Description and discussion. - According to Häntzschel (1975, W93-94), traces of the ichnogenus Phycodes consist of bundled unbranched and horizontal tunnels forming a "broomlike" pattern. The trace is characterized by a proximal unbranched tunnel, whereas the traces are branching distally into several free cylindric burrows that display a delicate annulation beneath a smooth "bark". The "broom-shaped" trace architecture of the single specimen in Fig. 4C strongly resembles that of Phycodes palmatum Hall, 1847 from the lower Cambrian of the Salt Range in Pakistan (Seilacher 1955; cf. also Häntzschel 1975, W94, Fig. 59-2e) but lacks the "delicate annulation".

\section{Treptichnus pedum (Seilacher, 1955) Figure 4D, E}

Description and discussion. - The ichnotaxon Treptichnus pedum (syn. Phycodes pedum, Trichophycus pedum) is used as an index fossil for the base of the Fortunian Stage and thus as a global indicator of the earliest Cambrian. The ichnogenus Treptichnus was first reported by Miller (1889) and later mentioned as "featherstich trail" by Wilson (1948) who describes the characteristic ichnomorphology of a treptichnid trace in which a "...straight or curved row of short individual burrows of equal length..." and which "... are arranged alternating to right and left resulting in a featherstitch pattern" (cit. from Häntzschel 1975, W117).

A couple of specimens of treptichnid traces were collected in the lower and middle parts of the Shitangshan section (lower Wulongqing Formation). The specimen in Fig. 4D displays a short row of elongated knob-shaped burrows (in positive hyporeliefs) in which these individual 
burrows join each other at low angles as short projections. This arrangement is characteristic of Treptichnus pedum (cf. Jensen 1997, Fig. 62B). The relation of Treptichnus pedum to the originally described (zigzag-shaped) ichnospecies Treptichnus bifurcus Miller, 1889 and also to Plangtichnus erraticus Miller, 1889 (cf. Archer \& Maples 1984) has been discussed by Jensen (1997). For a more detailed discussion of treptichnid traces and related synonymy see Jensen (1997). The row of circular knobshaped (hypichnically preserved) burrows in Fig. 4E apparently represents a certain type of lower-plane preservation of Treptichnus pedum cut off at another bedding plane level.

Jensen (1997) interpreted them as a series of dwelling tubes (domichnia), which possibly were inhabited by a suspension feeder sensu Bromley (1990). Recently, Vannier et al. (2010) showed that the trace architecture of the Palaeozoic Treptichnus pedum resembles the infaunal traces of recent priapulids. This aspect is of great interest for the interpretation of the ichnoassemblages and palaeoecology of the early Cambrian Chengjiang-type Lagerstätten because a large variety of priapulid worms were reported from the Chengjiang and the Guanshan biotas of Yunnan. Luo et al. (2008) described two taxa of priapulids (Guanduscolex minor $\mathrm{Hu}$, Luo \& Fu, 2008 and Palaeoscolex sp.) from the Guanshan Biota. Further taxa (Sicyphorus, Wudingscolex, Yunnanoscolex and Paramaotianshania) were recently reported from related sections by $\mathrm{Hu}$ et al. (2012). Some of them correspond in terms of their body size with the treptichnid traces from the middle Wulongqing Formation in the Shitangshan section.

\section{Teichichnus Seilacher, 1955}

Figure 4F, G

Description and discussion. - Teichichnus-type spreiten are common in the middle and upper parts of the Shitangshan section. They resemble Teichichnus from the (middle) Cambrian beds of Öland (south-eastern Sweden, Martinsson 1965) and the early Cambrian Mickwitzia sandstone (southern-central Sweden, Jensen 1997). The ichnogenus has been characterized by Häntzschel (1975, W114) as "a series of long horizontal burrows stacked vertical to bedding...". They represent wall-shaped laminar bodies of about 10 to $50 \mathrm{~cm}$ length, consisting of flat U-shaped gutters. The traces are generally not branching. Martinsson (1965) reported specimens up to $135 \mathrm{~cm}$ in length from the (middle) Cambrian of Öland (southern Sweden). This material was re-described by Schlirf \& Bromley (2007) as a new ichnotaxon (Teichichnus duplex). The type species (Teichichnus rectus Seilacher, 1955) was originally described as a "retrusive, tightly guided spreite". The only given differential feature of the second ichnospecies erected by
Legg (1985). Teichichnus ovillus Legg, 1985 is the existence of both retrusive and protrusive parts of spreiten. A protrusive or a retrusive spreiten architecture, however, may be simply caused by the reaction of a certain infaunal trace originator to a varying sedimentary regime (higher sedimentation rates or erosive phases, i.e. probably the same behavioural pattern in response to different environmental signals, and should be therefore avoided as an ichnotaxobase (see Fürsich 1974). According to Jensen (1997), the basic ichnomorphology of "teichichnia" (sensu Martinsson 1965) are "...flat U- or L-shaped burrows that were shifted upwards and in direction of burrow length, as a consequence of sediment influx".

The specimens from the Shitangshan section collected so far are relatively small ( $\mathrm{ca} 10-20 \mathrm{~cm}$ length of the spreiten), e.g. in relation to the (middle) Cambrian specimens from Öland. The short fragments (Fig. 4F) and the cross-cut spreite (Fig. 4G) represent the basic morphology of Teichichnus but do not provide sufficient taxonomic features for an ichnospecies determination.

\section{(iii) Short vertical burrows}

Figures 4H, 5A-F

Description and discussion. - The middle part of the $\mathrm{Wu}-$ longqing Formation in the Shitangshan quarry contains numerous, large, knob-shaped, vertical burrows of unknown origin. Jensen (1997) described and figured very similar structures from Baltica (early Cambrian Mickwitzia sandstone, Sweden). The burrows are sub-circular, mostly elongated to ellipsoid hyporeliefs, which frequently show a central pore or a short knob-shaped structure as a positive hyporelief in a shallow depression (Figs 4H, 5B-D). The ichnotaxonomic attribution of these burrows remains an open question; however, some of these specimens display remains of radially arranged rays (Fig. $4 \mathrm{H}$ ). Thus, some of them could represent vertical burrows (e.g. Figs 4H, 5D, E) of nearby completely destroyed specimens of large star-shaped vertical burrows (see below) that have been eroded by bottom-current activity. Parting lineation around some of these structures (Fig. 5E, F) may support this interpretation.

\section{(iv) Star-shaped traces}

Description and discussion. - The Guanshan ichnoassemblage contains large (up to some decimetres in diameter), star-shaped traces, which show several taxonomic similarities to the ichnogenus Glockerichnus Pickerill, 1982 (formerly "Glockeria” Książkiewicz, 1968; see also Häntzschel 1975 and Uchmann 1998). Because some of the star-shaped traces from the Wulongqing Formation display unusual and 
hitherto unknown taxonomic features, we present here a more detailed ichnotaxonomic study of these traces.

\section{Glockerichnus Pickerill, 1982}

Description and discussion. - Various ichnospecies of the ichnogenus Glockerichnus were originally described from Mesozoic and early Cenozoic (Cretaceous: Senonian to early Palaeogene) sequences in Europe by Książkiewicz (1968, 1970 and 1977): Glockerichnus glockeri Książkiewicz, 1968, Glockerichnus sparsicostata Książkiewicz, 1968 and Glockerichnus parvula Książkiewicz, 1970 (nomen nudum). Other related ichnotaxa are "Glockeria" disordinata Książkiewicz, 1977, "Glockeria” dichotoma Seilacher, 1977, and Glockerichnus alata (Seilacher, 1977).

The specimens of Glockerichnus glockeri described by Książkiewicz (1968, 1970, 1971) from the Polish Carpathian flysch are characterized by rosetted traces, consisting of numerous longer and shorter, straight and distally tapering rays (or "ribs", Książkiewicz 1970), which run radially from a diffuse central field (see sketch in Fig. 8A). The distal parts of some of the larger main ribs show a characteristic dichotomous branching, which was originally not mentioned by Książkiewicz (1970), but was assigned by Uchman (1998) as a distinct taxonomic feature of the ichnogenus Glockerichnus. The Carpathian specimens of Glockerichnus glockeri are up to $15 \mathrm{~cm}$ in diameter (after Książkiewicz 1970). The two other ichnospecies described by Książkiewicz $(1968,1970)$ are smaller, but largely similar to the ichnomorphology of Glockerichnus glockeri, and were also reported from the Polish flysch. The specimens of Glockerichnus sparsicostata and Glockerichnus parvula figured by Książkiewicz $(1968,1970,1971)$ display no convincing features of true ichnotaxabases. They could be poorly preserved specimens of the type species Glockerichnus glockeri. The much smaller (2-3 cm in diameter) "Glockeria" parvula (nomen nudum) was only tentatively attributed to "Glockeria" by Książkiewicz (1968, 1970) and may simply represent smaller and poorly preserved specimens of Glockerichus glockeri or, probably, the central areas of larger specimens of Glockerichnus. The type material of the Książkiewicz collection was restudied and revised by Uchman (1998).

Palaeoethology. - The ichnogenus Glockerichnus represents a distinct, star-shaped radiating (graphoglyptid) trace fossil (Pickerill 1982). Glockerichnus-type traces vary in size from $2-3 \mathrm{~cm}$ up to $20-30 \mathrm{~cm}$. The ethological classification of Glockerichnus was first given by Seilacher (1953) as a star-shaped fodinichnion (Seilacher 1955, 1959; Uchmann 1998). Glockerichnus may represent a combined domichnid-fodinichnid trace of an unknown infaunal trace originator which was stated again by Uchmann
(1998). Recent examples of star-shaped ichnia of similar shape and size are known, for example, from the Pacific ocean floor (Ewing \& Davis 1967), figured in Häntzschel 1970 (pl. 1, fig. a).

\section{(v) The star-shaped trace fossils from the Wulongqing Formation}

In comparison to the type-ichnospecies Glockerichnus glockeri from the Mesozoic-Cenozoic flysch of Poland, the star-shaped traces from the Wulongqing Formation show several similarities, but also a variety of different ichnotaxonomic features. We therefore suggest establishing a separate ichnotaxon.

\section{Guanshanichnus glockerichnoides igen. et isp. nov. Figures 6A, B, 7A-E, 9A-C}

Derivation of name. - Ichnogenus derived from the geographical name of the type area (Guanshan) as well as from the name of the fossil Lagerstätte and the related biota described from there (Guanshan Fauna). The ichnospecies name refers to the ichnomorphological similarities to Glockerichnus glockeri.

Holotype. - Specimen in Fig. 6A (NIGPAS collection, Nanjing Institute of Palaeontology, Nanjing, China (no collection number available so far).

Type locality and stratigraphy. - The trace fossil material described here was collected and photographed in the Shitangshan quarry close to the village of Guangwei, near Kunming, Yunnan Province, South China (Figs 1, 2). South Chinese regional biostratigraphical zonation: Wulonqing Formation [Palaeolenus Zone at the base and the Megapalaeolenus Zone (= Canglangpuan Stage)] at the top. Global biostratigraphic zonation of the Cambrian system: Stage 4, Series II ( ca 515-510 My). The Wulongqing Fauna can be correlated about with the Botoman of Siberia.

Material. - About 20 specimens, in different stages of preservation, partly in fragments. Some further specimens in large uncollectable slabs were measured and photographed in the field (e.g. Fig. 7A).

Diagnosis. - Short vertical burrows with a circular central structure. Starting from a broader proximal base, numerous ray-shaped, distally tapering and partly dichotomously branching ribs are arranged around the circular central field, forming a star-like structure on the sediment surface about 2 to $30 \mathrm{~cm}$ in diameter. The short vertical burrows 

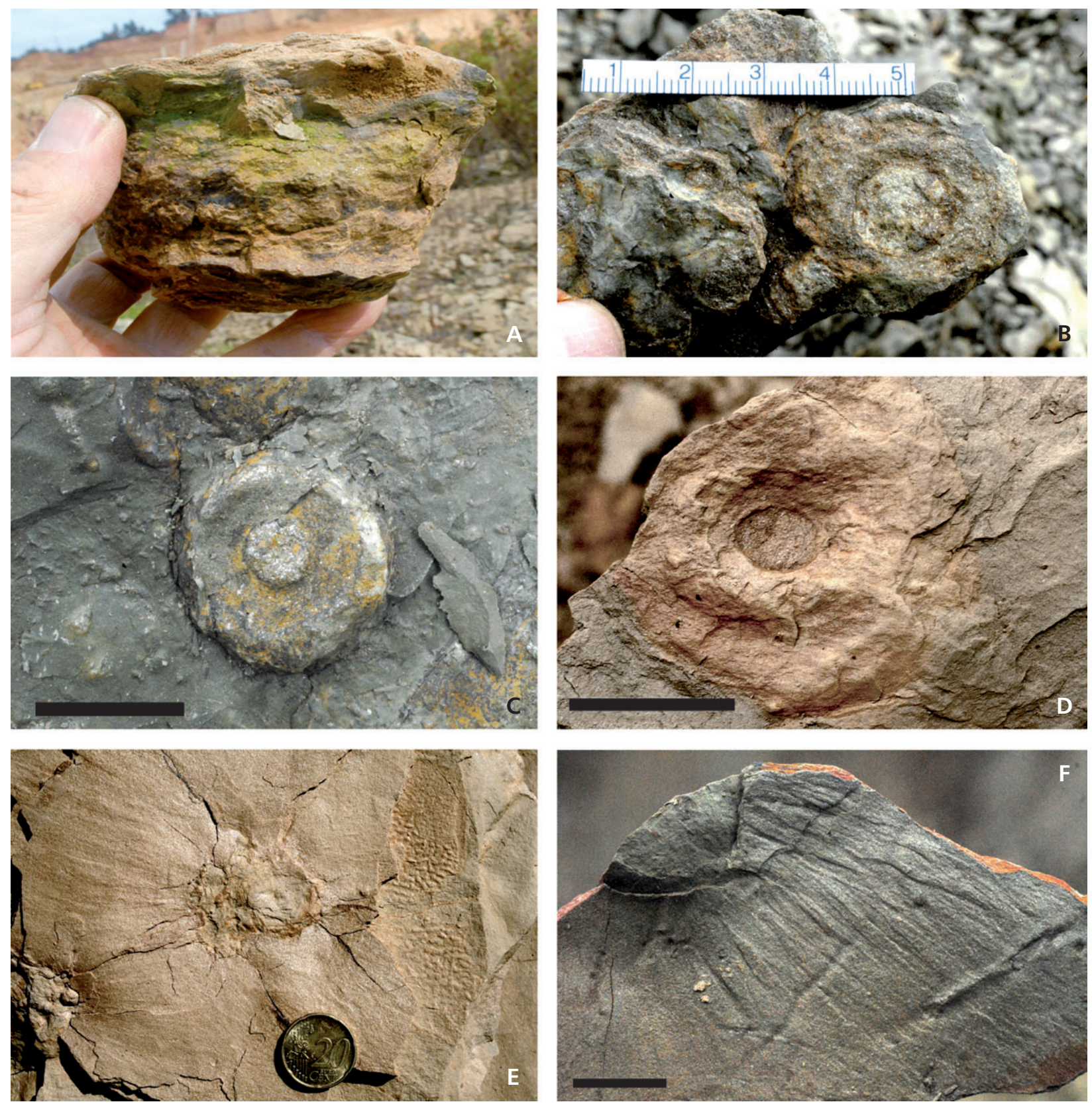

Figure 5. A - very large exichnial bell-shaped burrow structure which probably belongs to a large specimen of Guanshanichnus. $\bullet$ B-F - examples of varying preservations of large circular and short vertical burrows from the middle part of the Shitangshan section. $\bullet$ A-D showing the central depressions or knob-shaped elevations indicating a central vertical burrow. B and D show sub-circular elongation (ellipsoid shape) and E, F are associated with parting lineation structures indicating botton currents and erosional processes. Scales in F: $1 \mathrm{~cm}, \mathrm{~A}, \mathrm{C}, \mathrm{D}$ and coins: $2 \mathrm{~cm}$.

display a more or less cone- or bell-shaped (in crosssection funnel-shaped) structure.

Differential diagnosis. - (1) In contrast to the Mesozoic and Cenozoic specimens from Europe that all show relatively thick, spindle-shaped and transversally wrinkled ribs (e.g., Książkiewicz 1970, figs 7a-c; Książkiewicz 1977, pl. 8, figs 1-3; Uchman 1998, pp. 141-143; see also sketch in Fig. 8A herein), the star-shaped traces from the Guan- shan area (Wulongqing Formation) are characterized by many relatively thin (sometimes very thin), ray-shaped, partly dichotomously branching ribs, which show no transversal wrinkling and (starting from a broader proximal base at a circular central field) taper more or less continuously in a distal direction. (2) In contrast to Glockerichnus glockeri Książkiewicz, 1968 and the related ichnotaxa ("Glockeria" sparsicostata Książkiewicz, 1968; "Glockeria" parvula Książkiewicz, 1970, "Glockeria" disordinata 
Książkiewicz, 1977; "Glockeria” dichotoma Seilacher, 1977a; Glockerichnus alata Seilacher, 1977a), the new ichnotaxon Guanshanichnus glockerichnoides igen. et isp. nov. is characterized by a broad and prominent, circular, central area from which a large number of the distally tapering and partly dichotomously branching, ray-shaped structures radiate (type specimen: Fig. 6A, further specimens in Figs 6B, 7A-E), some preserved in large slabs (Figs 6B, 7A) and therefore partly not collectable. The star-shaped traces display a more or less completely circular radial structure and no evidence of a bilateral arrangement as reported for Glockerichnus glockeri by Uchmann (1998).

The Guanshanichnus structures are frequently associated with knob- or bell-shaped structures of approximately similar size ranges, commonly $1-3 \mathrm{~cm}$, in some cases up to more than $5 \mathrm{~cm}$ in diameter (Fig. 5A). Part of them could represent strongly weathered casts of the vertical burrows of Guanshanichnus. As some of them are additionally associated with parting lineation structures, bottom currents could have completely destroyed the primary radial surface structures and left the casts of the vertical burrow structures in the sediment body (see text above).

Stratigraphic range. - The stratigraphic range of the hitherto described occurrences of the similar and probably related ichnotaxon Glockerichnus glockeri ranges from the Ordovician of Chrustenice and Beroun in Bohemia (Richter 1927, Prantl 1946, Mikuláš 1998) and from the Early Ordovician Klabava Formation in Bohemia (Mikuláš 1992) to the Lower Cretaceous-Palaeogene of various European localities (Häntzschel 1970, pp. 211, 212), and may further range into Holocene and recent deep sea occurrences (Häntzschel 1970). The specimens from the Early Ordovician of Bohemia (Mikuláš 1992; esp. the specimen in pl. IV, fig. 2) show strong similarities to the specimens from the early Cambrian Guanshan Formation (see above). Thus, Guanshanichnus glockerichnoides igen. et sp. nov. represents an Early Palaeozoic occurrence (basal Cambrian) of this type of star-shaped ("Glockerichnuslike") vertical burrows.

Description and discussion. - The Wulongqing specimens of Guanshanichnus glockerichnoides igen. et isp. nov. range in size from about $2-8 \mathrm{~cm}$ up to $20-30 \mathrm{~cm}$ in diameter (Fig. 6A, B) and show a dichotomous branching of the radial and distally tapering rays similar to that of Glockerichnus glockeri; however, in contrast to Glockerichnus, the large and well-preserved specimens of Guanshanichnus glockerichnoides igen. et isp. nov. from the Wulong- qing Formation display a circular star-shaped structure consisting of thin, ray-shaped burrows, which are arranged in large numbers around a prominent circular central area (Figs 6A, B, 7A-E). The basic morphology (i.e., the dichotomously branching rays), is identical with that of Glockerichnus glockeri; however, the numerous ray-shaped burrows are relatively thin in relation to Glockerichnus glockeri. In some cases (Figs 6B, 7A-C), they resemble very thin and multiple-branching rays, whereas the radial burrows in Glockerichnus glockeri and related ichnotaxa are generally thicker and mostly spindle-shaped (see re-drawn sketch from Książkiewicz 1968, Fig. 8A). This is clearly a differential feature in relation to the type species of Guanshanichnus glockerichnoides igen. et isp. nov. and cannot be explained by any diagenetic or preservational phenomena. On the other hand, the newly described ichnotaxon displays a broad variety of different preservations (Figs 6A, B, 7A-E) and sizes (about 2-8 up to $30 \mathrm{~cm}$ ). Smaller and poorly preserved specimens were only mentioned (not figured), and tentatively attributed by $\mathrm{Hu}$ et al. (2010) to Astropolichnus cf. hispanicus.

Along with the different shape and higher number of ribs, the second characteristic differential feature of Guanshanichnus glockerichnoides igen. et isp. nov. is the mostly well-visible, circular central area in the star-shaped traces, whose diameter can vary significantly in different specimens (see above). In some specimens, the circular central area displays a very prominent, broad circular structure (Figs 6A, B, 7D). In weathered specimens (Fig. 9C), the centre of the star-shaped structure appears more diffuse or may show only a smaller and rather faintly preserved central vertical burrow (Fig. 7B). Larger specimens can display small central circles ( $c f .6 \mathrm{~A}, 7 \mathrm{~A}, \mathrm{C})$, whereas relatively small specimens can possess a relatively large circular structure (Figs 7D, E, 9B). This phenomenon can be explained (1) by different qualities of preservation of the traces and (2) by representing different horizontal planes through the short vertical (funnel-shaped) central burrows (sketch in Fig. 8B). Therefore, it may not inevitably indicate the occurrence of different trace types (i.e., different ichnospecies of Guanshanichnus) in the Shitangshan ichnoassemblage but could represent simply a preservational phenomenon. Häntzschel (1970) figured a specimen (pl. 1, fig. b) as a "star-like trace" from the Kimmeridgian-Lower Tithonian flysh of Bielsko, Polish Carpathians. This specimen displays a small, circular, central burrow that was not mentioned in the taxonomic description of "Glockeria" by Książkiewicz (1968); however, the specimen displays relatively thick spindle-like

Figure 6. A - holotype specimen of Guanshanichnus glockerichnoides igen. et isp. nov. from the upper Shitangshan section. • B - another large specimen of Guanshanichnus glockerichnoides that also displays the relative large circular central field and the numerous and very thin distally branching rays (specimen belongs to slab in Fig. 7A), scale: $2 \mathrm{~cm}$. 

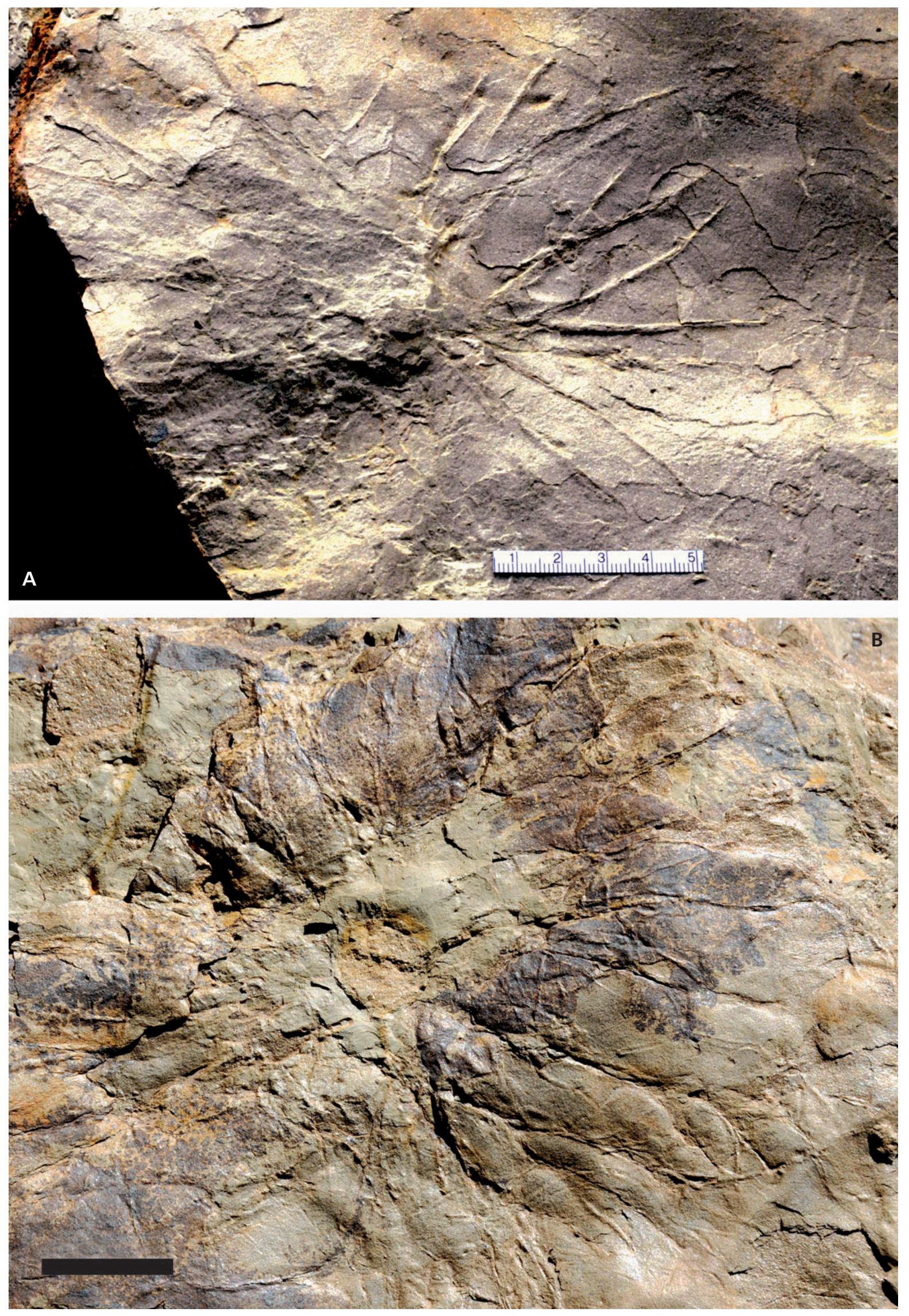
rays and therefore could instead represent a specimen of Glockerichnus glockeri. Mikuláš (1992) figured an early Ordovician specimen from Bohemia that displays similarities with Guanshanichnus glockerichnoides igen. et isp. nov. as it shows a faint circular central field and numerous thin and distally tapering ray-shaped, radially arranged burrows similar to those in the Shitangshan specimens. Finally, the Glockerichnus isp. from siliceous marls (Turonian, Carpathian Mts: Książkiewicz collection material) which was re-figured in Uchmann (1998, figs 47A, B) displays numerous thin rays (but a diffusely preserved central area), and may be attributed to Guanshanichnus. Finally, Zhu (1997, figs 5A, B) figured a specimen of an unnamed star-shaped trace from the Shiyantou Formation of Meishucun that displays a relative large circular central field and short, distally tapering, partly branching rays. This ichnomorphology matches perfectly those of the smaller specimens of Guanshanichnus glockerichnoides (Fig. 7D).

Uchman (1998) emphasized that Glockerichnus always occurs in flysch deposits between the Ordovician and Miocene. The flysch deposits represent deep water environments (upper slope to deep sea facies). During the Mesozoic and Cenozoic eras, these environments are commonly characterized by typical deep-water ichnotaxa such as Lorenzinia, Paleodictyon, etc. The occurrence of the ("Glockerichnus-like") star-shaped traces of the Guanshanichnus type in the Botoman Shitangshan ichnoassemblage, however, is characterized by a different palaeoenvironment, belonging to a near-shore shallow water regime. The associated diverse ichnoassemblage contains fodinichnid, domichnid and repichnid ichnotaxa (e.g., Planolites, Teichichnus, (?) Thalassinoides and arthropod repichnia (such as Diplichnites, Merostomichnites), which all represent characteristic members of the shallow-marine Cruziana ichnofacies. On the basis of this ichnofacies data, the depositional environment of the host sediments of the Guanshan Biota can therefore be characterized as shallow marine softgrounds which were deposited between fair-weather and storm-wave bases, resulting in a sequence of mudstone and sandstone beds. The Ordovician finds of Glockerichnus reported by Mikuláš $(1992,1998)$ also clearly belong to shallow seas, outside flysch/turbidite sedimentation areas.

The unknown trace makers of the early Palaeozoic Guanshanichnus traces were obviously still adapted to shallow water conditions, whereas later Phanerozoic representatives of this trace type gradually moved into deeper shelf and deep sea habitats during Late Palaeozoic to Cenozoic times. On the other hand, combined star-shaped domichnia and fodinichnia represent a common type of trophic strategies in benthic (infaunal and epifaunal) organisms and therefore could have been produced by taxonomically very different invertebrate trace makers in both shallow marine and deep water environments (i.e., during early Palaeozoic and younger deposits, respectively).

\section{Other problematic star-shaped structures}

Several problematic stellate structures were found in the middle part of the Wulongqing section (Figs 9D, E, 10E). They consist of five to six radially arranged, pear-shaped (convex) lobes or lobate depressions and are preserved as three-dimensional casts (hyporeliefs) or as flat impressions whose surfaces are covered by yellowish-red iron oxides. Well-preserved specimens show a central plug (probably the end part of a short vertical burrow), have a constant diameter of 5-7 $\mathrm{mm}$ and (if preserved as a positive hyporelief) are $2-3 \mathrm{~mm}$ high. Similar problematic structures have been reported from the early Cambrian of the Arumbera section (Amadeus Basin, central Australia) by Walter et al. (1989). These authors compared the Amadeus basin specimens with Asterichnus isp.; however, the former lack the characteristic features of a retrusive spreite that are evident in Asterichnus. The problematic stellate structures from the Wulongqing Formation are smaller than the Australian specimens. The specimens from the Shitangshan quarry display similarities in their shape (but not in their size range) to the problematic star-like fossils "Palaeosemaestoma" from the Lower Jurassic of Germany (Sehnde, Lower Saxony) as figured by Häntzschel (1970, p. 207, pl. 2, fig. b). Finally, the traces resemble the ichnogenus Gyrophyllites Glocker, 1841 (Häntzschel 1975, W66, 2a, b) from the European Flysch (Upper Cretaceous); however, an arrangement of the radiating leaf-shaped spreiten in different levels as described in Gyrophyllites (Häntzschel 1975, W65) is not preserved in the Shitangshan specimens. Thus, the trace fossil assignment and origin of the structures here described (Figs 9D, $\mathrm{E}, 10 \mathrm{E})$ remain unclear.

\section{(vi) Arthropod traces}

In comparison with the high number of other invertebrate traces, arthropod traces are rarely occurring in the whole Wulongqing Formation so far and are mainly restricted to the middle part of the section (Fig. 2A). Along with nonspecific series of arthropod scratch marks, short trackways of Diplichnites-type traces consisting of two paired rows of scratches were found (Fig. 9G, H) as well as a typical Merostomichnites (Fig. 10C).

\section{Diplichnites Dawson, 1873}

Figures 9G, H, 10A

Description and discussion. - The traces commonly consist of two series of short (straight or gently curved) ridges, each 3-5 mm in length. Some specimens from the Wulongqing section are large (10-20 $\mathrm{mm}$ in width) and up to $10 \mathrm{~cm}$ in 

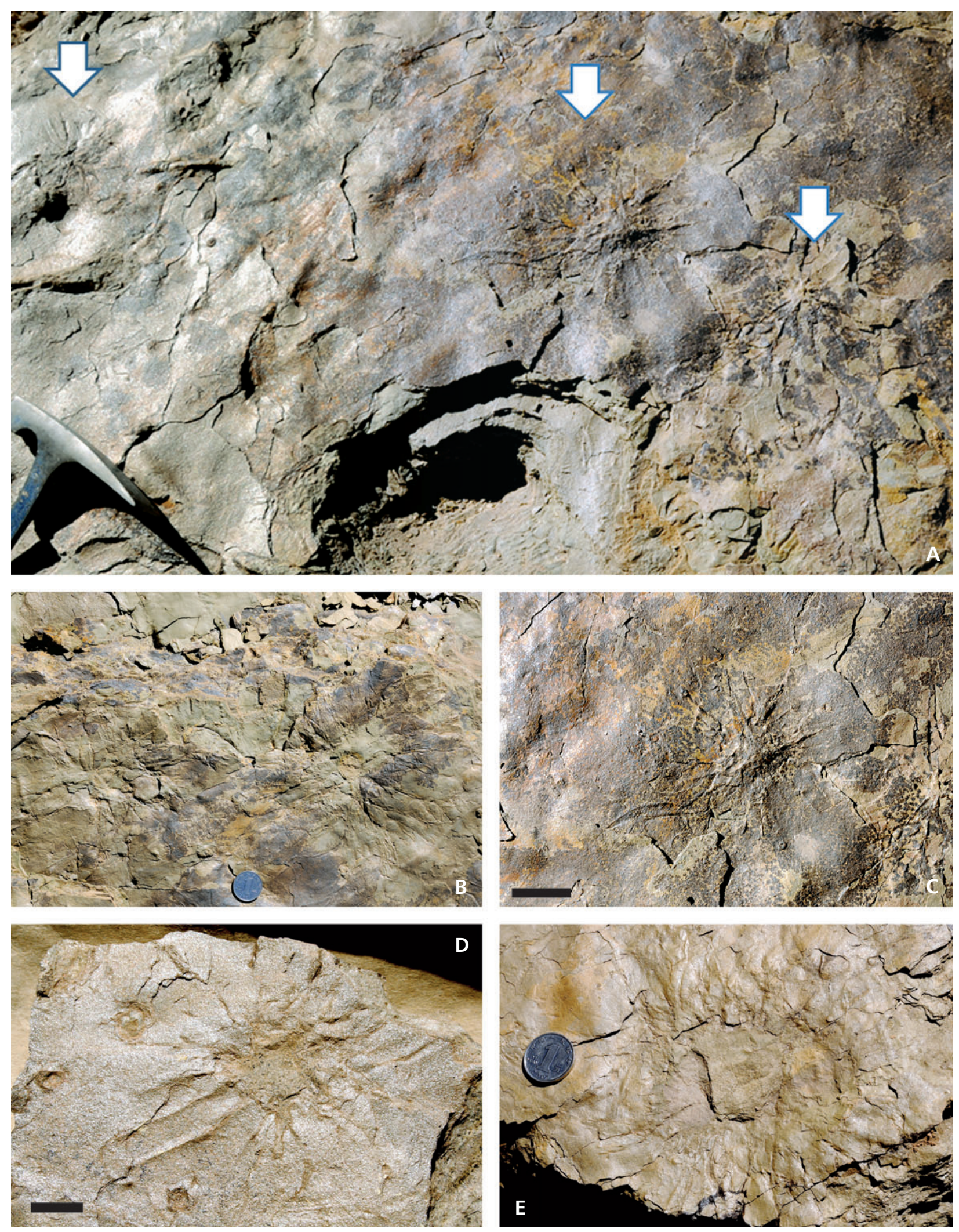

Figure 7. A - an uncollectable slab (in situ) with numerous specimens of Guanshanichnus glockerichnoides (arrows), hammer head: about $20 \mathrm{~cm}$. - B-E - examples of different preservations of Guanshanichnus in the Shitangshan section (see discussion), collections of the FUB Berlin. Scales in 7C, D: $1 \mathrm{~cm}$, coins: $2 \mathrm{~cm}$. 

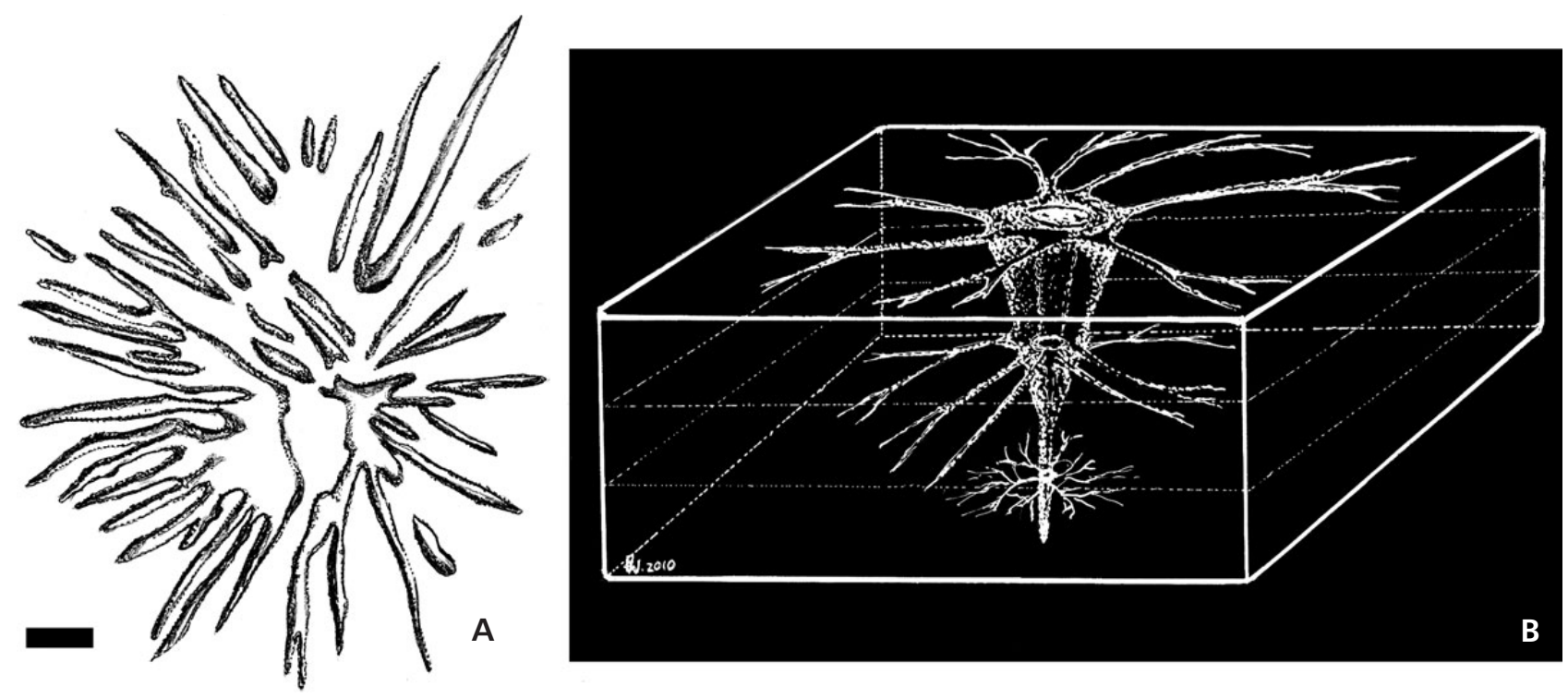

Figure 8. A - re-drawing of a sketch of Glockerichnus glockeri (from Kziaskiewicz 1970, fig. 7a) which displays the characteristic elongate spindle-shape of the rays in G. glockeri. • B - reconstruction of Guanshanichnus glockerichnoides igen. et isp. nov. showing the (probably retrusive) development of the funnel-shaped vertical burrows with radially arranged and branching rays (probes) in different levels of development of the trace structure which may have caused the variability of the trace type by preservation of different developmental stages.

length. Series of bulbous hyporeliefs may represent faint undertrack preservations of Diplichnites (Fig. 9H).

The Diplichnites-type traces represent repichnia of epibenthic arthropods, in many cases those of trilobites. The ichnogenus Diplichnites occurs in several other Cambrian shallow marine environments, e.g., in Australia (Walter et al. 1983), Pakistan (Seilacher 1955), Canada (Young 1972), Spain (Crimes et al. 1977) and in the Nomtsas Formation, Namibia (Crimes \& Germs 1982). The youngest occurrence of Diplichnites is in the lower Permian (Walter et al. 1989).

\section{Merostomichnites Packard, 1900}

Figure 10C

Description and discussion. - The trace in Fig. 10C represents a unique but well-preserved specimen of Merostomichnites. This arthropod trace type is characterized by two (or more) parallel rows (at approx. $1 \mathrm{~cm}$ intervals) of single spindle- or bow-shaped impressions, partly ornamented with oblique transverse ring-shaped structures. $M e$ rostomichnites is known from Cambrian to lower Triassic occurrences in Europe and North America. The youngest evidence of a Diplichnites-like trace was reported by Kim et al. (2005) from the Cretaceous. The Palaeozoic traces were attributed to trilobites and eurypterids, whereas the Mesozoic specimens may belong to phyllocarids (Häntzschel 1975) or other benthic crustaceans.

The unique specimen from the Wulongqing Formation in Fig. 10C represents the first evidence of Merostomichnites-type traces from the early Cambrian of China. They were most probably produced by several redlichid trilobite taxa, which are commonly preserved as body fossils in the intercalated mudstone beds of the Wulongqing Formation (Fig. 10B).

\section{Trilobite resting traces}

The specimen in Fig. 10A displays a V-shaped arrangement of obliquely orientated bifid ridges. This arrangement agrees in shape and size with the morphology (thorax and abdominal parts) of several trilobite taxa from the Guanshan Fauna and for that reason can be interpreted as a resting trace of a trilobite. The specimen in Fig. 10A therefore may be interpreted as a rarely preserved transitional form of Diplichnites-type repichnia and a Rusophycus-type resting

Figure 9. A - close-up photo of a branching ray (probe) from the holotype specimen (6A) showing the thin and continuously tapering rays in Guanshanichnus glockerichnoides igen. et isp. nov. $\bullet$ B, C - examples of small (probably early developmental stages) and partly weathered or eroded specimens demonstrating the preservational variability of the ichnotaxon. $\bullet \mathrm{D}, \mathrm{E}-$ problematic small star-like trace fossils from the upper Shitangshan section. The traces display a rosette-like shape of radially arranged lobes (partly 3D-preserved -9D). $\bullet \mathrm{F}$ - example of similar rosette-shaped vertical traces in a recent shallow marine environment (South-China Sea) which are produced by small crustaceans (photo: Hu Shixue). $\bullet \mathrm{G}, \mathrm{H}-\mathrm{examples}$ of hyporelief-preservations of Diplichnites from the lower-middle part of the Shitangshan section. Scales in A, B and coins: $1 \mathrm{~cm}, \mathrm{D}, \mathrm{E}: 0.5 \mathrm{~cm}, \mathrm{~F}, \mathrm{H}: 1 \mathrm{~cm}$. 
Bernd Weber et al. • Ichnofauna from the Cambrian Stage 4, South China
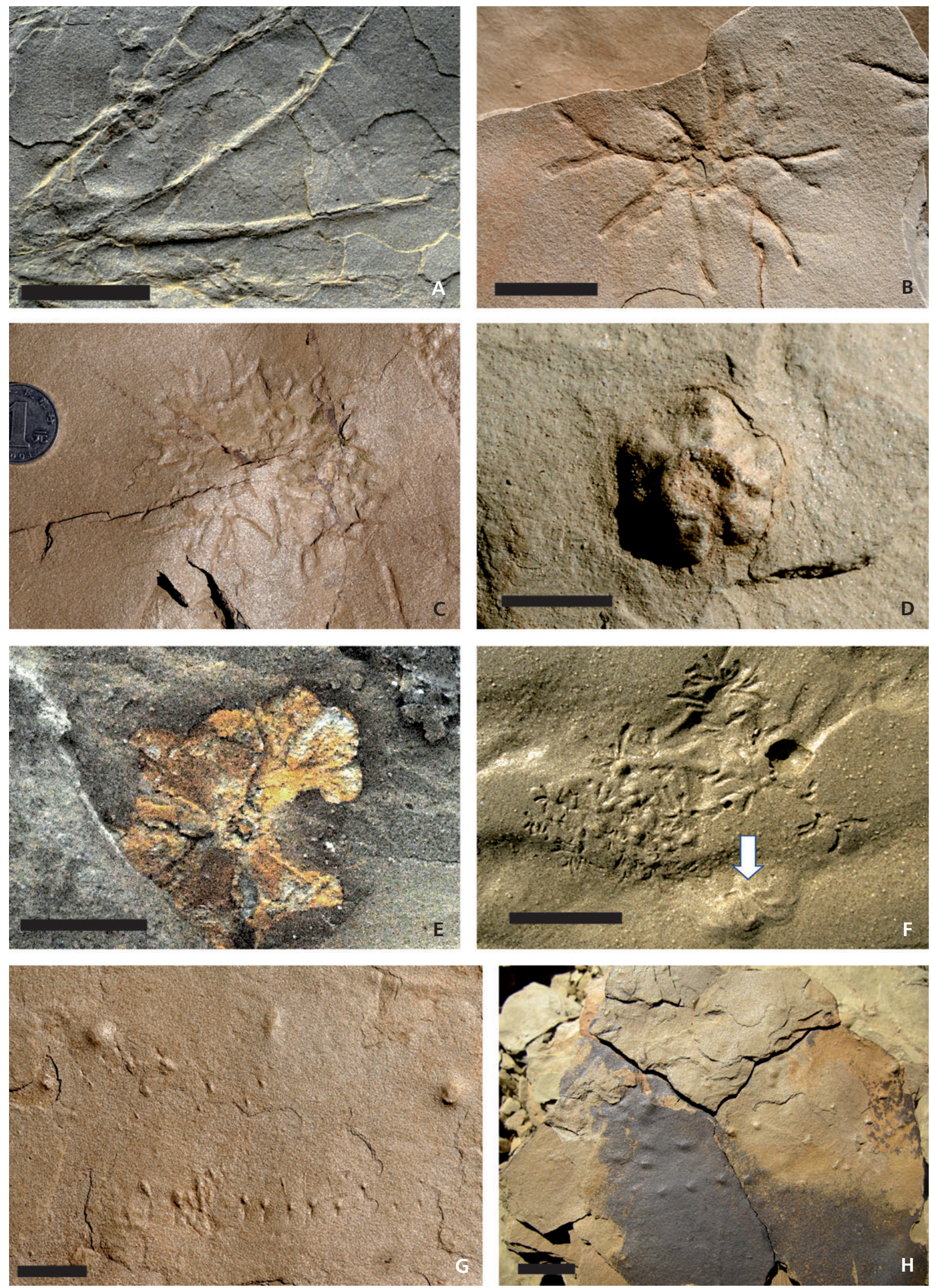

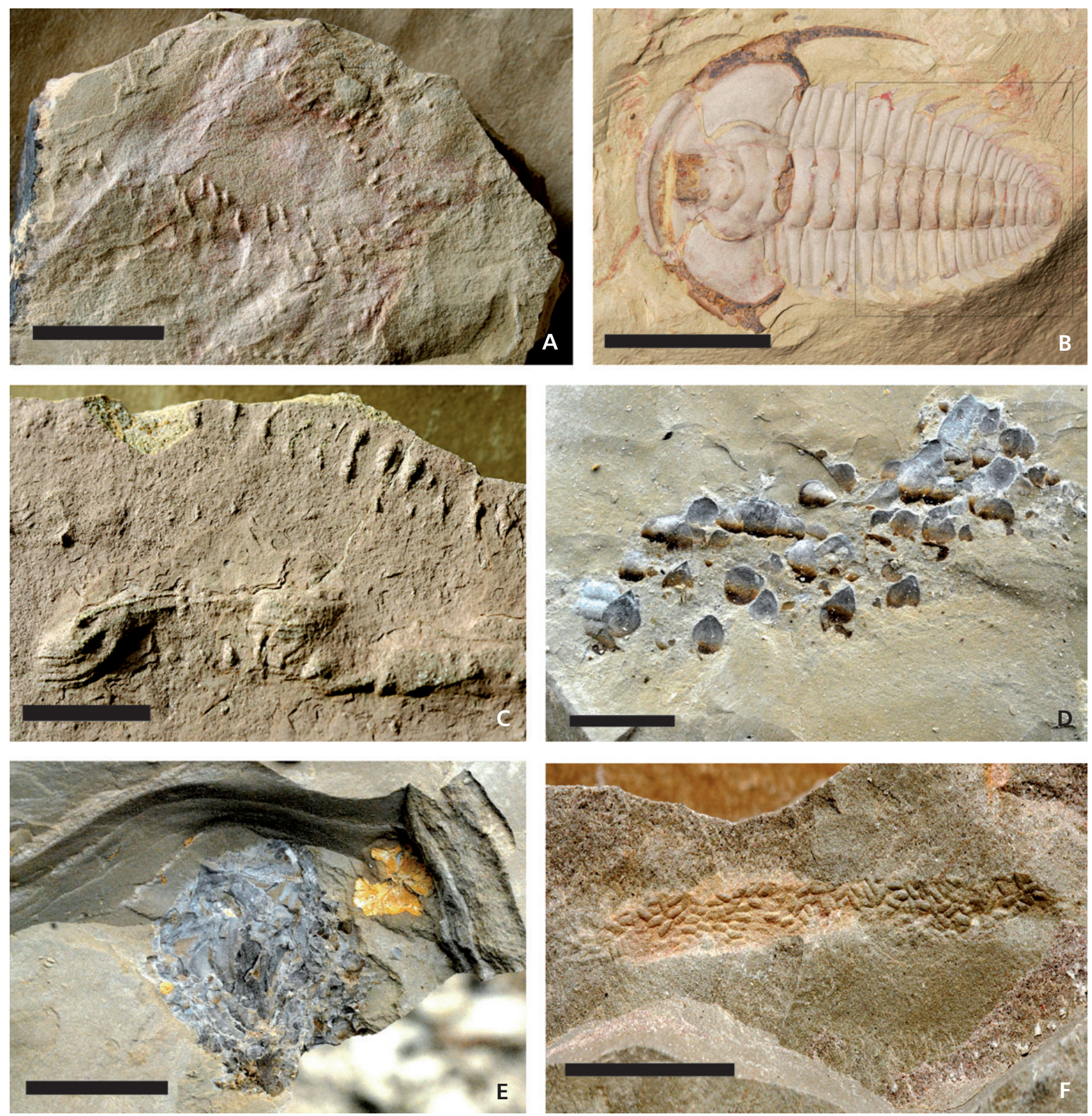

Figure 10. A, B - U-shaped arrangement of single impressions of Diplichnites-type arthropod traces (A) correlate in their shape and size range with coinciding typical redlichide trilobit taxa (Redlichia mansuyi Resser \& Endo, 1937, fig. 10B). They therefore may be interpreted as transitional forms of Diplichnites-type repichnia and Rusophycus-type digging/resting traces of trilobites. $\bullet$ C - Merostomichnites isp. is known by a single specimen from the Shitangshan section. The single impressions in the Shitangshan specimen display the characteristic oblique annulation of Merostomichnites-type arthropod traces. $\bullet$ D - accumulation of intact shells of lingulid brachiopods. Such accumulations may be interpreted both as coprolites of a specialized predator and as result of current-related transport of shells and their subsequent allochthonous embedding (e.g. in microbial mucus). $\bullet \mathrm{E}$ - example of a frequently found coprolite type consisting of shreddered and fragmented parts of arthropod (probably trilobite) carapaces indicating the presence of larger predators (e.g. predatory arthropods as anomalocarids) in the Guanshan Biota. $\bullet \mathrm{F}-$ the problematic ichnogenus Tomaculum Groom, 1902 was repeatedly found in the Shitangshan section. The here figured example of a long, hose-like structure filled with ellipsoid feacal pellets strongly resembles Tomaculum problematicum from the Palaeozoic of Europe. Scales in A, B, E: $2 \mathrm{~cm}$, D-F: $1 \mathrm{~cm}$. 
trace. Regarding the average size and morphology, the co-occurring trilobite Redlichia mansuyi Resser \& Endo, 1937 (Fig. 10B) from the Shitangshan quarry may represent a possible originator of this unique resting trace.

\section{(vii) Faecal pellets (coprolites)}

Figures 10D-F

Faecal pellets and coprolites are considered to be trace fossils as they represent the result of a physiological process as well as the behaviour of a living organism. In exceptionally well-preserved cases, coprolites enable the reconstruction of specific ecological interactions (e.g. between prey and predator: food chains) within a fossil ecosystem.

\section{Tomaculum Groom, 1902}

Figure 10F

Several specimens of long and bedding-parallel (Planolites-like), mostly flattened sausage-shaped structures or longer tubes filled with numerous ellipsoid faecal pellets (Fig. 10F) were found in the Shitangshan section.

A similar structure from an approximately time-equivalent outcrop in Wushishan (Wuding County, Yunnan) was described and figured by Luo et al. (2008, p. 133, pl. 39, fig. 4) as Tomaculum problematicum Groom, 1902. The ichnospecies has been earlier reported, e.g. by Volk (1941) from the Ordovician of Thuringia (Germany), and was recently revised and critically discussed in terms of the problematic taxonomy and interpretation of Tomaculum by Eiserhardt et al. (2001).

\section{Other non-specific faecal pellets}

Figure 10 D, E

Various ball- or sausage-shaped accumulations consisting of shells of lingulid brachiopods (Fig. 10D) and/or of fragmented arthropod (mainly trilobite) carapaces (Fig. 10E) are relatively common in the Wulongqing Formation and may represent faecal lumps of predators. The relatively large pellets of shredded arthropod carapaces (Fig. 10E) may indicate the hunting and feeding activity of the largest Chengjiang predators Anomalocaris Whiteaves, 1892 and Amplectobelua Hou, Bergström \& Ahlberg, 1995 which both are characteristic elements of the Chengjiang-type biotas. The identification of the sausage-shaped accumulation of intact lingulid shells (Fig. 10D) as coprolites, however, remains problematic. Such shelly accumulations could also be caused by short-distance transportation of the shells by a weak bottom current and their final trapping by a microbially caused mucus production (microbial mats mentioned above, Fig. 3C).

\section{Discussion and conclusions - Palaeoenvironment and composition of the ichnofauna}

The depositional regime of the Wulongqing Formation has been reconstructed by $\mathrm{Hu}$ et al. (2010) as a storm-dominated subtidal to offshore transitional palaeoenvironment. Sedimentary structures of the mudstone-siltstone sequence of the Wulongqing Formation indicate sedimentation in a shallow marine palaeoenvironment between fair-weather and storm-wave bases. The related ichnoassemblage described above (Cruziana ichnofacies) is consistent with this interpretation.

The horizons with Chengjiang-type softpart preservation indicate rapid autochthonous deposition shortly after storm events, whereas the silty beds with fragmented trilobite carapaces and brachiopod shells point to a parauthochthonous depositional regime in which carcasses of shelly invertebrates were transported locally by bottom currents (see parting lineation, see Fig. 5E, F) or by storm waves over short distances to their burial sites. Alternating horizons with intense bioturbation (e.g., beds with simple Planolites-type trace fossils) could indicate a more ephemeral feeding activity and mass propagation of opportunistic infaunal consumers appearing in the nutrient-rich beds deposited after storm events. Other beds with various vertical burrows, star-shaped traces and arthropod repichnia and cubichnia may be interpreted as the more regular infaunal and epifaunal activity of invertebrates occupying the sea floor between the storm events. The frequent ripple marks and especially the common occurrence of characteristic wrinkle marks (Fig. 3C) in the mudstone-siltstone beds demonstrates the abundance of microbial mats in the Wulonqing sequence and additionally indicates their deposition under shallow marine conditions within the photic zone. The proximal setting and the co-occurrence of beds with Chengjiang-type soft-part preservation of invertebrates (early Cambrian fossil Lagerstätte, $\mathrm{Hu}$ et al. 2010) and beds with episodic high levels of bioturbation (Fig. 3B) within the Wulongqing sequence extend our knowledge about the possible variety of palaeoecology and the related faunal inventary of Chengjiang-type fossil Lagerstätten (Hu et al. 2010).

\section{Acknowledgements}

The authors thank the Deutsche Forschungsgemeinschaft (DFG) and the National Natural Science Foundation of China (NSFC: Grant No. 40772020, 41002002) as well as the Chinese Academy of Sciences (KZCX-EW-115) for funding the Chinese-German research project within Forschergruppe 736. We also thank A. Uchmann (Krakow) and the reviewers, S. Jensen (Badajoz) and R. Mikuláš (Praha) for their constructive discussions and advice. 


\section{References}

Archer, A.W. \& Maples, C.G. 1984. Trace-fossil distribution across a marine to- nonmarine gradient in the Pennsylvanian of south-western Indiana. Journal of Palaeontology 58, 448-466.

Banks, N.L. 1970. Trace fossils from the late Precambrian and Lower Cambrian of Finnmark, Norway, 19-34. In CRIMES, T.P. \& HARPER, C. (eds) Trace Fossils 1. Geological Journal, Special Issue 9.

BilLings, E. 1862. New species of fossils from different parts of the Lower, Middle and Upper Silurian rocks of Canada, 96-168. In Palaeozoic Fossils, Volume 1 (1861-1865). 426 pp. Geological Survey of Canada \& Dawson Brothers, Montreal.

Bromley, R.G. 1990. Trace fossils: Biology and taphonomy. 260 pp. Unwin \& Hyman, London.

Bromley, R.G. 1996. Trace fossils. Biology, taphonomy and applications. 361 pp. Chapman \& Hall, London.

Cowie, J.W. \& Spencer, A.M. 1970. Trace fossils from the late Precambrian/Lower Cambrian of East Greenland, 91-100. In CRIMES, T.P. \& HARPER, C. (eds) Trace fossils 1. Geological Journal, Special Issue 9.

Crimes, T.P. \& Germs, G.J.B. 1982. Trace fossils from the Nama Group (Precambrian - Cambrian) of South-West Africa (Namibia). Journal of Paleontology 56(4), 890-907.

Crimes, T.P., Legg, I., Marcos, A. \& Arboleya, M. 1977. ?Late Precambrian-low Lower Cambrian trace fossils from Spain, 91-138. In Crimes, T.P. \& HARPER, C. (eds) Trace fossils 2. Geological Journal, Special Issue 9.

Dornbos, S.Q., BotTJer, D.J. \& Chen, J.Y. 2004. Evidence for seafloor microbial mats and associated metazoan lifestyles in Lower Cambrian phosphorites of Southwest China. Lethaia 37(2), 127-137. DOI 10.1080/00241160410004764

DzIK, J. 2007. The Verdun Syndrome: Simultaneous origin of protective armour and infaunal shelters at the PrecambrianCambrian transition. The Geological Society of London, Special Publications 286, 405-414. DOI 10.1144/SP286.30

EHRENBERG, K. 1944. Ergänzende Bemerkungen zu den seinerzeit aus dem Miozän von Burgschleintz beschriebenen Gangkernen und Bauten dekapoder Krebse. Paläontologische Zeitschrift 23, 354-359.

Eiserhardt, K.-H., Koch, L. \& Eiserhardt, W.L. 2001. Revision des Ichnotaxons Tomaculum Groom, 1902. Neues Jahrbuch für Geologie und Paläontologie, Abhandlungen 221(3), 325-358.

Ekdale, A.A., Bromley, R.G. \& Pemberton, S.G. 1984. Ichnology: The use of trace fossils in sedimentology and stratigraphy. 317 pp. Society of Economic Paleontologists and Mineralogists, Tulsa.

Emmons, E. 1844. The Taconic System: based on observations in New York, Massachussetts, Maine, Vermont and Rhode Island. 68 pp. Caroll \& Cook, Albany.

EwING, M. \& DAvis, R.A. 1967. Deep sea photography - Lebensspuren photographed on the ocean floor. Oceanographic Studies 3, 259-294.
Fedonkin, M.A. 1985. Palaeoichnology of the Vendian Metazoa, 132-137. In Sokolov, B.S. \& Iwanowski, A.B. (eds) The Vendian System, Volume 1. Paleontology. Springer, Berlin.

Fillion, D. \& PickeriLl, R.K. 1990. Ichnology of the Upper Cambrian? to Lower Ordovician Beii Island and Wabana groups of eastern Newfoundland, Canada. Palaeontographica Canadiana $7,1-119$.

FIтCH, A. 1850. A historical, topographical and agricultural survey of the County of Washington, Part 2-5. Transactions of the New York State Agricultural Society 9, Albany, 753-944.

FÜRSICH, F.T. 1974. On Diplocraterion Torell, 1870 and the significance of morphological features in vertical, spreite-bearing, U-shaped trace fossils. Journal of Paleontology 48, 952-962.

Gabbott, S.E., Hou, X.G., Norry, M.J. \& Siveter, D.J. 2004. Preservation of Early Cambrian animals of the Chengjiang biota. Geology 32, 901-904.

Gehling, J.G., Jensen, S., Droser, M.L., Myrow, P.M. \& NARBONNE, G.M. 2001. Burrowing below the basal Cambrian GSSP, Fortune Head, Newfoundland. Geological Magazine 138(2), 213-218. DOI 10.1017/S001675680100509X

Geyer, G. \& Uchman, A. 1995. Ichnofossil assemblages from the Nama Group (Neoproterozoic-Lower Cambrian) in Namibia and the Proterozoic-Cambrian boundary problem revisited. Beringeria, Special Issue 2, 175-202.

Hall, J. 1847. Palaeontology of New York. Volume I. 338 pp. C. van Benthuysen, Albany.

HäntZsChEL, W. 1970. Star-like trace fossils, 201-214. In Crimes, T.P. \& HARPer, J.C. (eds) Trace fossils 1. Geological Journal, Special Issue 3.

HÄNTZSCHEL, S. 1975. Trace fossils and problematica, W1-W269. In MoOre, R.C. \& TeICHERT, C. (eds) Treatise on invertebrate paleontology. Part W, Supplement 1. Geological Society of America \& University of Kansas, Boulder \& Lawrence.

Hofmann, H.J. 1981. First record of a Late Proterozoic faunal assemblage in the North American Cordillera. Lethaia 14, 303-310. DOI 10.1111/j.1502-3931.1981.tb01103.x

Hofmann, H.J. \& Patel, I.M. 1989. Trace fossils from the type 'Etcheminian Series' (Lower Cambrian Ratcliffe Brook Formation), Saint John area, New Brunswick, Canada. Geological Magazine 126, 139-157. DOI 10.1017/S0016756800006294

Hou, X.G., Aldridge, R.J., Bergström, J., Siveter, David J., Siveter, Derek J. \& Feng, X.H. 2004. The Cambrian fossils of Chengjiang, China: The flowering of early animal life. 248 pp. Blackwell Publishing, Malden \& Oxford. DOI 10.1002/9780470999950

Hu, S.X., Steiner, M., Zhu, M.Y., Luo, H., Forchielli, A., Keupp, H., Zhao, F.C. \& Liu, Q. 2012. A new priapulid assemblage from the early Cambrian Guanshan fossil Lagerstätte of SW China. Bulletin of Geosciences 87(1), 93-106. DOI 10.3140/bull.geosci.1238

Hu, S.X., Zhu, M.Y., Steiner, M., Luo, H.L., Zhao, F.C. \& QI, L. 2010. Biodiversity and taphonomy window of the early Cambrian Guanshan biota, eastern Yunnan. Science China - Earth 
Sciences 53(12), 1765-1773.

DOI 10.1007/s11430-010-4086-9

Hucke, K. 1967. In Voigt, E. (ed.) Einführung in die Geschiebeforschung. $132 \mathrm{pp}$. Nederlandse Geologische Vereniging, Oldenzaal. [in German]

Ivantsov, A.Y., Zhuravlev, A.Y. \& Leguta, A.V. 2005. Palaeoecology of the Early Cambrian Sinsk biota from the Siberian Platform. Palaeogeography, Palaeoclimatology, Palaeoecology 220 (Supplement), 69-88.

DOI 10.1016/j.palaeo.2004.01.022

JAEGER, H. \& MARtinsson, A. 1980. The Early Cambrian trace fossil Plagiogmus in its type area. Geologiska Förenings $i$ Stockholms Förhandlingar 102(2), 117-126.

DOI 10.1080/11035898009450888

Jensen, S. 1997. Trace fossils from the Lower Cambrian Mickwitzia sandstone, south-central Sweden. Fossils \& Strata 42, $1-111$.

Jensen, S. 2003. The Proterozoic and Earliest Cambrian Trace Fossil Record; Patterns, Problems and Perspectives. Integrative \& Comparative Biology 43, 219-228.

DOI 10.1093/icb/43.1.219

KAPPEL, J. 2002. Ichnofossilien im Campanium des südöstlichen Münsterlandes. 236 pp. Ph.D. thesis, Mathematisch-naturwissenschaftliche Fakultät der Westfälischen WilhelmsUniversität, Münster. [in German]

KENNEDY, W.J. 1967. Burrows and surface traces from the Lower Chalk of southern England. Bulletin of the British Museum of Natural History, Geology 15, 127-167.

Kim, J.Y., Keighley, D.G., Pickerill, R.K., Hwang, W. \& Kim, K.-S. 2005. Trace fossils from marginal lacustrine deposits of the Cretaceous Jinju Formation, southern coast of Korea. Palaeogeography, Palaeoclimatology, Palaeoecology 218, 105-124. DOI 10.1016/j.palaeo.2004.12.008

KsIĄżKIEWICZ, M. 1968. O niektorych problematykack z flisz Karpat polskich Czesc III. Rocznik Polskiego Towarzystwa Geologicznego 38, 3-17. [in Polish]

Ksiaż̇KIEWicz, M. 1970. Observations on the ichnofauna of the Polish Carpathians, 283-322. In CRIMES, T.P. \& HARPER, J.C. (eds) Trace fossils 1. Geological Journal, Special Issue 3.

KsiĄżkiewicz, M. 1977. Trace fossils in the Flysch of the Polish Carpathians. Palaeontologica Polonica 36, 1-208.

LEGG, I.C. 1985. Trace fossils from a Middle Cambrian deltaic sequence, north Spain, 151-165. In Allen Curran, H. (ed.) Biogenic structures: their use in interpreting depositional environments. Society of Economic Paleontologists and Mineralogists, Special Publiction 35.

LuO, H.L., JiANG, Z.W. \& TANG, L.D. 1994. Stratotype Section for Lower Cambrian Stages in China. 183 pp. Yunnan Science and Technology Press, Kunming. [in Chinese with English abstract]

LuO, H.L., Hu, S.X., ChEn, L.Z., Zhang, S.S. \& TAO, Y.H. 1999. Early Cambrian Chengjiang Fauna from Kunming region, China. 129 pp. Yunnan Science and Technology Press, Kunming. [in Chinese with English summary]

Luo, H.L., Li, Y., Hu, S.X., Fu, X.P., Hou, S.G., Liu, X.Y., CHEN, L.Z., Li, F.J., PANG, J.Y. \& Liu, Q. 2008. Early Cambrian
Malong Fauna and Guanshan Fauna from Eastern Yunnan, China. 134 pp. Yunnan Science and Technology Press, Kunming. [in Chinese with English summary]

Martinsson, A. 1965. Aspects of a Middle Cambrian Thanatotope on Öland. Geologiska Förenigens i Stockholms Förhandlingar 87, 181-230. DOI 10.1080/11035896509448903

McIlroy, D. \& HeYs, G.R. 1997. Palaeobiological significance of Plagiogmus arcuatus from the lower Cambrian of central Australia. Alcheringa 21, 161-178. DOI 10.1080/03115519708619171

MikUláš, R. 1992. Trace fossils from the Klabava Formation (Early Ordovician), Czechoslovakia. Acta Universitatis Carolinae, Geologica 3-4, 385-419.

MikULÁš, R. 1998. Trace fossils from the Letná Formation (Ordovician, Czech Republic). Sborník geologických věd, Paleontologie 34, 5-24.

Miller, S.A. 1889. North American geology and palaeontology for the use of amateurs, students and scientists. 664 pp. Western Methodist Book Concern, Cincinnati, Ohio.

DOI 10.5962/bhl.title.28778

Myrow, P.M. 1995. Thalassinoides and the enigma of Early Paleozoic open-framework Burrow Systems. Palaios 10, 58-74. DOI 10.2307/3515007

Nicholson, H.A. 1873. Contributions to the study of the errant annelids of the older Palaeozoic rocks. Proceedings of the Royal Society of London 21, 288-290.

DOI 10.1098/rspl.1872.0061

NowaK, W. 1957. Quelques hieroglyphes etoiles des Karpates de Flysch exterieures. Annales Societatis geologorum Poloniae 26, 187.

Osgood, R.G. 1970. Trace fossils of Cincinnati area. Palaeontographica Americana 6(41), 281-444.

Paterson, J.R. \& Brock, G.A. 2007. Early Cambrian trilobites from Angorichina, Flinders Ranges, South Australia, with a new assemblage from the Pararaia bunyerooensis Zone. Journal of Paleontology 81(26), 116-142.

DOI 10.1666/0022-3360(2007)81[116:ECTFAF]2.0.CO;2

PeEL, J.S. 2010. Articulated hyoliths and other fossils from the Sirius Passet Lagerstätte (early Cambrian) of North Greenland. Bulletin of Geosciences 85(3), 385-394.

DOI 10.3140/bull.geosci.1207

Pemberton, S.G. \& Frey, R.W. 1982. Trace fossil nomenclature and the Planolites-Palaeophycus dilemma. Journal of Paleontology 56(4), 843-881.

Pen, J., Zhao, J.L. \& Wu, Y.S. 2005. The Balang Fauna - A new early Cambrian Fauna from Kaili City, Guizhou Province. Chinese Science Bulletin 50(11), 1159-1162.

DOI 10.1360/982005-183

PICKERILL, R.K. 1982. Glockerichnus - A new name for the trace fossil ichnogenus Glockeria Ksiazkiewicz, 168. Journal of Paleontology 56(1), 816.

Ponomarenko, A.G. (ed.) 2005. Unique Sinsk Localities of Early Cambrian Organisms (Siberian Platform). Transactions of Palaeontological Institute 284. 143 pp. Nauka, Moscow. 
Porada, H., Ghergut, J. \& Boudugri, E.-H. 2008. Kinneyia-type wrinkle structures - critical review and model of formation. Palaios 23, 65-77.

Prantl, F. 1946. Two new problematic trails from the Ordovician of Bohemia. Academie tchèque des sciences, Bulletin international, Classe des sciences mathematiques et naturelles et de la medicine 46(1945), 49-59.

RichTER, R. 1927. Die fossilen Fährten und Bauten der Würmer. Ein Überblick über ihre biologischen Grundformen und deren geologische Bedeutung. Paläontologische Zeitschrift 9, 195-240. [in German]

RichTER, R. 1937. Marken und Spuren aus allen Zeiten. Senckenbergiana 19(1), 150-169. [in German]

RoEDEL, H. 1929. Ergänzung zu meiner Mitteilung über ein kambrisches Geschiebe mit problematischen Spuren. Zeitschrift für Geschiebeforschung 5, 48-52. [in German]

RoHDE, A. 2009. Hardeberga-Sandstein mit dem Spurenfossil Psammichnites gigas aus dem Geschiebe. Teichichnus duplex n. isp., new trace fossil from the Cambrian and the Triassic. Beringeria 37, 133-141.

Seilacher, A. 1953. Studien zur Palichnologie (II). Neues Jahrbuch für Geologie und Paläontologie, Abhandlungen 98(1), 87-124. [in German]

SeIlAcher, A. 1955. Spuren und Fazies im Unterkambrium, 373-399. In Schindewolf, O.H. \& Seilacher, A. Beiträge zur Kenntnis des Kambriums in der Salt Range (Pakistan). Akademie der Wissenschaften und der Literatur zu Mainz, Mathematischnaturwissenschaftliche Klasse, Abhandlungen 10. [in German]

SeILACher, A. 1959. Zur ökologischen Charakteristik von Flysch und Molasse. Eclogae Geologicae Helvetiae 51, 1062-1078. [in German]

Seilacher, A. 1977. Pattern analysis of Paleodictyon and related trace fossils, 289-334. In Crimes, T.P. \& HARPER, J.C. (eds) Trace fossils 2. Geological Journal, Special Issue 9.

ToRELL, O.M. 1868. Bidrag till Sparagmitetagens geognosi och paleontologi. Lunds Universitets Arskrift 4, part 2, 1-40.

Torell, O.M. 1870. Petrificata Suecana Formationis Cambricae. Lunds Universitets Arskrift 6(8), part 2, 1-14.
Uchmann, A. 1998. Taxonomy and ethology of flysch trace fossils: Revision of the Marian Ksiazkiewick collection and studies of complementary material. Annales Societatis geologorum Poloniae 68, 105-218.

Vannier, J., Calandra, I., Gaillard, C. \& Źylińska, A. 2010. Priapulid worms: Pioneer horizontal burrowers at the Precambrian-Cambrian boundary. Geology 38(8), 711-714. DOI 10.1130/G30829.1

Volk, M. 1941. Die Lebensspur Tomaculum problematicum Groom auch im Griffelschiefer des Thüringer Ordoviziums. Senckenbergiana 23, 123-126. [in German]

Walter, M.R., Elphinstone, R. \& Heys, G.R. 1989. Proterozoic and Early Cambrian trace fossils from the Amadeus and Georgina Basins, central Australia. Alcheringa 13(3), 209-256. DOI 10.1080/03115518908527821

WiLson, A.E. 1948. Miscellaneous classes of fossils, Ottawa Formation, Ottawa - St.Lawrence Valley. Geological Survey of Canada, Department of Mines and Resources, Bulletin 5(11), $1-116$.

YANG, S. 1984. Silurian trace fossils from the Yangzi gorges and their significance to depositional environments. Acta Palaeontologica Sinica 23, 705-715.

YounG, F.G. 1972. Early Cambrian and older trace fossils from the Southern Cordillera of Canada. Canadian Journal of Earth Sciences 9(11), 1-17. DOI 10.1139/e72-001

Yue, W., Lin, J.P., Zhao, Y.L. \& ORR, P.J. 2009. Palaeoecology of the trace fossil Gordia and its interaction with nonmineralizing taxa from the early Middle Cambrian Kaili Biota, Guizhou province, South China. Palaeogeography, Palaeoclimatology, Palaeoecology 277(1-2), 141-148. DOI 10.1016/j.palaeo.2009.02.017

Zhang, X.L. \& HuA, H. 2005. Soft-bodied fossils from the Shipai Formation. Lower Cambrian of the Three Gorges area, South China. Chinese Science Bulletin 142(5), 1-11.

Zhu, M.Y. 1997. Precambrian-Cambrian trace fossils from Eastern Yunnan, China: Implications for Cambrian explosion. Bulletin of National Museum of Natural Sciences 10, 275-312. 